\title{
Treating Advanced Unresectable or Metastatic HER2-Positive Breast Cancer: A Spotlight on Tucatinib
}

\section{Lara Ulrich \\ Alicia FC Okines}

Department of Breast Oncology, The Royal Marsden Hospital NHS Foundation Trust, London, UK
Correspondence: Alicia FC Okines The Royal Marsden NHS Foundation Trust, Fulham Road, London, SW3 6JJ

Tel +4420781 18100

Fax +442078118197

Email Alicia.Okines@rmh.nhs.uk

\begin{abstract}
The management of HER2 positive breast cancer has been transformed by the development of targeted therapies. Dual blockade with the monoclonal antibodies, trastuzumab and pertuzumab, added to first-line taxane chemotherapy and second-line therapy with the antibody-drug conjugate, T-DM1, are internationally agreed standards of care for advanced HER2 positive breast cancer, where available. However, until recently, options for patients for third-line therapy and beyond were of modest efficacy or limited by toxicity. In 2019, the results of trials of two exciting new agents for this space were presented. A third-generation HER2 tyrosine kinase inhibitor, tucatinib, combines the efficacy of the second-generation drug, neratinib, with a more manageable toxicity profile and has become a new standard of care after T-DM1, in combination with capecitabine and trastuzumab. The antibody-drug conjugate, trastuzumab deruxtecan, demonstrated remarkable efficacy in heavily pre-treated patients and received accelerated approval in the United States, whilst confirmatory Phase 3 trials are completed. This review will discuss the available data for the post-T-DM1 setting, focusing on tyrosine kinase inhibitors including tucatinib.
\end{abstract}

Keywords: central nervous system, CNS, HER2-positive, metastatic breast cancer, tucatinib, tyrosine kinase inhibitor

\section{Introduction}

Despite the significant progress in the multimodality treatment of breast cancer over the last twenty years, it remains the second largest contributor to cancer mortality worldwide. $^{1,2}$ Approximately $20 \%$ of invasive breast cancers over-express the HER2 receptor, which manifests as a more aggressive phenotype, with a greater probability of disease relapse and a tropism for the central nervous system (CNS). ${ }^{3,4}$ Historically patients with HER2 positive (HER2+) breast cancer had a poor prognosis, but with the evolution of targeted anti-HER 2 therapies and dual HER2 antibody blockade, the median survival of patients with HER2+ metastatic breast cancer (MBC) now approaches 5 years. ${ }^{5}$

Trastuzumab, a humanised anti-HER2 monoclonal antibody acts by blocking activation of the dimerised HER2 receptor, in addition to triggering antibodydependent cell-mediated cytotoxicity $(\mathrm{ADCC})^{6}$ (Figure 1). The landmark randomised controlled trial of trastuzumab added to chemotherapy demonstrated a $49 \%$ reduction in the risk of progression as well as superior overall survival (0S) compared to chemotherapy alone (25.1 vs 20 months, Hazard ratio (HR) 0.80, 


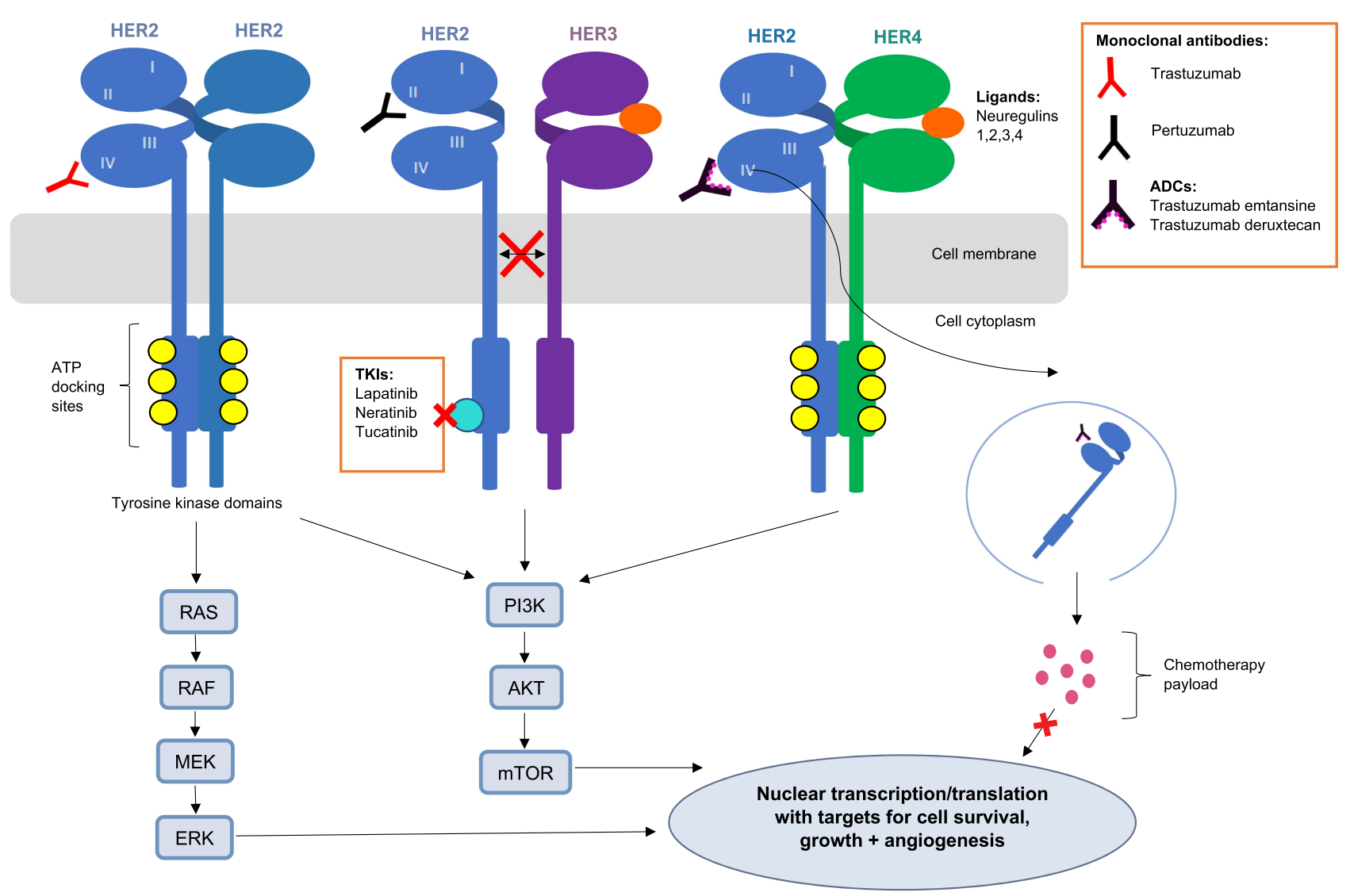

Figure I The HER2 receptor and its drug targets.

Abbreviations: ADCs, antibody-drug conjugates; TKIs, tyrosine kinase inhibitors; ATP, adenosine triphosphate.

$95 \%$ confidence interval (CI) $0.80-1.00, \mathrm{p}-0.0046)$, transforming the management of HER2+ breast cancer. ${ }^{7}$

Several mechanisms of primary and acquired resistance to trastuzumab have been described (reviewed ${ }^{8}{ }^{8}$. Mutations which cause a conformational change or shedding of the external domain of HER2 produce a truncated version of the HER2 receptor (p95 HER2), preventing the binding of trastuzumab, thereby abrogating its efficacy. ${ }^{9}$ The introduction of tyrosine kinase inhibitors (TKIs), small molecules which can bypass the extracellular domain and inhibit the kinase directly, facilitates blockade of the HER2 pathway in the presence of acquired resistance due to p95 HER2. ${ }^{10}$ Rare activating mutations encoding the tyrosine kinase domain will also lead to constitutive activation and resistance to trastuzumab $^{11}$ which has generated the concept of 'vertical blockade', using both monoclonal antibodies and TKIs simultaneously. ${ }^{12}$

Central nervous system (CNS) spread was recognised as an emerging problem in HER2+ MBC following the introduction of trastuzumab, which significantly improved survival but appeared unable to prevent CNS disease. ${ }^{13}$ Regrettably, up to $50 \%$ of patients with HER2+ MBC will ultimately develop parenchymal brain metastases. ${ }^{14,15}$ The efficacy of intravenous monoclonal antibodies is limited for CNS disease, secondary to their relative inability to cross both the blood brain barrier (BBB) and blood tumour barrier (BTB): the delivery of trastuzumab to the CNS was investigated in murine in vivo models and only $5 \%$ of the injected dose was found to reach brain tumours, irrespective of their size. ${ }^{16}$ The concentration of trastuzumab in the CNS can be increased by disrupting the integrity of the BBB with concurrent radiotherapy, ${ }^{17}$ especially if the intravenous monoclonal antibody is delivered at high dose, however, response rates remain modest. ${ }^{18}$ For patients with leptomeningeal disease, intrathecal (IT) delivery of trastuzumab has been investigated in Phase 1 studies following case reports of promising responses. ${ }^{19,20}$ No dose-limiting toxicities (DLTs) were reported at the maximum tolerated dose (MTD) for IT trastuzumab (150 mg weekly), with 3 of 16 patients experiencing clinical responses, so Phase 2 evaluation is ongoing. ${ }^{21}$ 
It is a widely accepted strategy, that patients with intracranial relapse alone should continue current systemic therapy alongside CNS radiotherapy for sustained extracranial control. ${ }^{22,23}$ Increasingly, stereotactic radiosurgery (SRS) is accepted as the strategy of choice to treat multiple brain metastases to avoid the cognitive side-effects of whole brain radiotherapy (WBRT). ${ }^{22-24}$ The median survival for patients with HER2+ brain metastases amenable to SRS is approximately 2 years. ${ }^{25}$ Given the potentially incapacitating side effects of WBRT, there is a demand therefore for a third-line systemic agent with sufficient CNS efficacy to delay the need for WBRT in patients encumbered by a high volume of CNS disease, not amenable to (further) SRS.

HER2-directed TKIs are small molecules which compete for the ATP-binding domain located on the intracellular portion of the HER2 receptor (Figure 1), inhibiting phosphorylation and preventing activation of downstream signalling pathways. ${ }^{26,27}$ Unlike monoclonal antibodies, they can cross the cell membrane into the cytoplasm. ${ }^{26}$ By targeting the intracellular domain, any conformational changes affecting the extracellular receptor will be circumvented. Furthermore, their relatively low molecular weight theoretically allows them to cross the BBB more effectively to target CNS disease. ${ }^{14}$ There are currently three FDA-approved TKIs: lapatinib, neratinib and most recently, tucatinib. The irreversible EGFR, HER2 and HER4 inhibitor, afatinib was also investigated in phase 3 trials in HER2 positive breast cancer, ${ }^{28,29}$ but minimal activity and significant toxicity were demonstrated; therefore, the development in breast cancer was ceased. Two further TKIs, poziotinib and pyrotinib, have also shown promising response rates in phase $1 / 2$ trials conducted in China and the US. ${ }^{30-33}$

\section{Scope of This Review}

We will focus on the role of anti-HER2 TKIs, primarily in the third-line setting, where there is no agreed standard of care. ${ }^{34}$ The majority of these data evaluate combinations of TKIs with chemotherapy, trastuzumab or both. This review will describe the efficacy of TKIs in CNS disease, considering outcomes of time to CNS relapse and time to CNS intervention in addition to survival benefits.

The significant dermatological and gastrointestinal toxicities associated with first- and second-generation TKIs (lapatinib and neratinib) ${ }^{35,36}$ have necessitated the development of a more selective HER2 TKI with proven CNS efficacy. Randomised Phase II data for tucatinib from the pivotal HER2CLIMB trial will be discussed and its role assessed in the future paradigm of third-line treatment for metastatic HER2+ breast cancer. Relevant clinical trials in progress will also be highlighted.

\section{Standard of Care for Ist and 2nd Line Treatment}

The CLEOPATRA trial defined a new first-line standard for HER2+ MBC, demonstrating significant prolongation of median progression-free survival (PFS) and OS from the addition of pertuzumab to first-line docetaxel plus trastuzumab. ${ }^{5}$ The PERUSE trial confirmed similar efficacy when paclitaxel was substituted for docetaxel. ${ }^{37}$ The administration of a more effective systemic therapy appears to be one effective strategy to delay the development of brain metastases in patients with advanced breast cancer. Dual anti-HER2 targeting with docetaxel, trastuzumab and pertuzumab in the CLEOPATRA trial, which excluded patients with CNS disease, demonstrated the triplet significantly reduced the time to CNS relapse by 3.1 months compared to docetaxel, trastuzumab and placebo (Hazard ratio (HR) 0.58, $\mathrm{p}=0.0049$ ). ${ }^{5,38}$ However, the CNS was the first site of progression in $12.6 \%$ of patients receiving pertuzumab and $13.7 \%$ receiving placebo. ${ }^{38}$

The pivotal EMILIA phase 3 randomised controlled trial (RCT) compared the antibody-drug conjugate, T-DM1 with capecitabine/lapatinib in a population of patients all previously treated with trastuzumab and a taxane. T-DM1 demonstrated a statistically significant improvement in median PFS (9.6 vs 6.4 months, HR 0.65; 95\% Confidence interval (CI) $0.55-0.77, \mathrm{P}<0.001)$ and median OS (30.9 vs 25.1 months, HR $0.68,95 \%$ CI 0.$55-0.85, \mathrm{P}<0.001)$ compared to lapatinib/capecitabine. ${ }^{39}$ Furthermore, the response rate for T-DM1 reached $43.6 \%$ compared to $30.8 \%$ for capecitabine/lapatinib, ${ }^{39}$ establishing T-DM1 as the new standard after trastuzumab/taxane failure. The THER3SA trial demonstrated the efficacy of T-DM1 in a more heavily pre-treated population, again reporting improved survival. ${ }^{40}$ In contrast, the MARIANNE trial failed to bring T-DM1 into the firstline setting, reporting no benefit from combination of T-DM1 with pertuzumab, and non-inferiority but not superiority to taxane plus trastuzumab. ${ }^{41}$

An exploratory analysis of patients with asymptomatic CNS metastases in the EMILIA trial $(n=95)$ demonstrated a numerically higher rate of CNS progression in patients 
treated with T-DM1 compared to capecitabine/lapatinib, both in patients with (2.0 vs $0.9 \%)$ and without $(22.2 \%$ versus $16.0 \%$ ) brain metastases at baseline. Despite this, the significant improvement in median OS with T-DM1 was retained in patients with brain metastases compared to lapatinib/capecitabine (26.8 vs 12.9 months, HR 0.38 , $\mathrm{P}=0.008) .^{40}$ These data suggest that combination of T-DM1 and a TKI should be explored to maximise intraand extra-cranial disease control. The phase IIIB Kamilla study was designed to confirm the efficacy of T-DM1 in a larger cohort of HER2+ MBC patients including patients with brain metastases. ${ }^{42}$ A CNS response ( $\geq 30 \%$ reduction in the sum of the diameters) was observed in $42.9 \%$ of the $126 / 398$ patients with measurable CNS disease, and $49.3 \%$ of the 67 patients who had not received prior radiotherapy. $^{42}$

\section{Lapatinib}

Lapatinib is a dual, oral, reversible TKI which targets EGFR (HER1) and HER2. Early clinical trials demonstrated lapatinib's efficacy as a monotherapy with an overall response rate (ORR) of $23.8 \%$ in trastuzumab-refractory disease, suggesting its ability to overcome acquired resistance in almost a quarter of patients. ${ }^{43}$ Synergy of lapatinib with trastuzumab providing "vertical blockade" of HER2 was demonstrated in HER2+ breast cancer cell lines. ${ }^{12}$ The phase 3 EGF104900 trial confirmed this observation in a randomised comparison of trastuzumab and lapatinib vs lapatinib alone in patients previously exposed to three trastuzumab-containing regimens. The trastuzumab/lapatinib combination improved median PFS from 8.1 to 11.1 weeks (HR 0.75, 95\% CI 0.58-0.94, $\mathrm{p}=0.011$ ) and median OS from 9.5 to 14 months (HR 0.74 , 95\% CI $0.57-0.97$, $\mathrm{p}=0.026){ }^{44}$ Importantly, symptomatic cardiac events were not significantly increased by dual HER2 blockade. This combination remains a useful, chemotherapy-free option with a tolerable side effect profile for heavily pre-treated HER2+ MBC patients. ${ }^{45}$

Furthermore, the addition of lapatinib to chemotherapy significantly improved PFS and OS: Combination with paclitaxel improved median OS by 7 months compared with paclitaxel alone in newly diagnosed HER2 MBC (HR 0.74; 95\% CI, 0.58-0.94, $\mathrm{p}=0.0124) .{ }^{46}$ However, the NCIC CTG MA.31 study failed to demonstrate superiority of lapatinib/taxane to trastuzumab/taxane in the first-line setting and burdened patients with higher rates of diarrhoea (19 vs 1\%) and skin toxicity (8 vs $0 \%) .{ }^{47}$ This naturally led to further evaluation in the trastuzumab- resistant setting: The EGFR100151 phase 3 RCT evaluated the addition of lapatinib (50mg/day) to capecitabine $\left(2000 \mathrm{mg} / \mathrm{m}^{2}\right.$ days $1-14$ of a 21-day cycle) in a population of HER2+ MBC patients who had received prior therapies including trastuzumab, taxanes and anthracyclines. The combination significantly improved time to progression (TTP) to 8.4 vs 4.4 months (HR 0.49 ; 95\% CI $0.34-0.71, \mathrm{p}<0.001)$ without significant addition of grade 3-4 (G3-G4) toxicity or symptomatic cardiac events. ${ }^{48}$ Although there was a trend towards an OS benefit at the final analysis, crossover to lapatinib after the interim analysis resulted in insufficient power to detect an OS benefit. $^{48}$ The role of lapatinib and capecitabine in the second-line setting has now been largely superseded by T-DM1 in view of the striking EMILIA trial results discussed previously. ${ }^{39}$ Table 1 summarises the randomised phase 2 and 3 trials of TKIs in HER2+ MBC.

For patients with oestrogen receptor (ER) positive and HER2+ disease, blockade of HER2 can switch the cancer's allegiance and dependence to hormone-driven cellsignalling pathways, postulating combined blockade of HER2 and ER as an effective strategy to overcome resistance. ${ }^{49}$ The addition of lapatinib to first-line letrozole reduced the risk of progression with median PFS prolonged from 3.0 to 8.2 months (HR $0.71,95 \% \mathrm{CI}$ $0.53-0.96, \mathrm{p}=0.019) .{ }^{50}$ A subsequent study evaluated triple blockade with lapatinib, trastuzumab and an aromatase inhibitor (AI) compared to the AI with either one anti-HER2 agent, and reported superiority of the triplet (median PFS 11 vs 5.6 months with AI/trastuzumab, HR $0.62,95 \%$ CI $0.45-0.88, \mathrm{p}=0.0063) .{ }^{51}$ The randomised phase II PERTAIN trial similarly reported improved median PFS with trastuzumab, pertuzumab plus an AI compared to trastuzumab plus AI alone (HR 0.65; 95\% CI, $0.48-0.89 ; \mathrm{p}=0.0070){ }^{52}$ Despite $42 \%$ of patients not receiving induction chemo, the median PFS was 18.9 months; similar to that reported with docetaxel in the CLEOPATRA trial. Median survival was also similar to that reported in CLEOPATRA, irrespective of whether patients received induction chemotherapy. ${ }^{53}$ As such, first-line endocrine therapy plus anti-HER2 targeting is an important option for the treatment of women with "triple positive" MBC who are unsuitable for taxane chemotherapy. Furthermore, maintenance endocrine therapy with trastuzumab and pertuzumab following completion of first-line taxane chemotherapy is the standard of care for women with ER+ and HER2+ advanced disease. $^{45}$ 
Table I Randomised Trials of Anti-HER2 Tyrosine Kinase Inhibitors in Advanced HER2-Positive Breast Cancer

\begin{tabular}{|c|c|c|c|c|c|c|c|c|c|}
\hline Trial & Phase & Setting & Arms & $\begin{array}{l}\text { Previous } \\
\text { Treatment }\end{array}$ & $\mathbf{N}$ & $\begin{array}{l}\text { ORR } \\
\text { (\%) }\end{array}$ & $\begin{array}{l}\text { Median PFS } \\
\text { (Months) }\end{array}$ & $\begin{array}{l}\text { Median OS } \\
\text { (Months) }\end{array}$ & Safety Profile \\
\hline \multirow{2}{*}{$\begin{array}{l}\text { NCIC CTG } \\
\text { MA.3I, } \\
\text { GELMON ET } \\
\text { AL }(2015)^{47}\end{array}$} & \multirow[t]{2}{*}{ III } & \multirow[t]{2}{*}{ Ist line } & $\begin{array}{l}\text { Trastuzumab }+ \\
\text { taxane }\end{array}$ & \multirow[t]{2}{*}{ Nil } & \multirow[t]{2}{*}{537} & 75.9 & 13.6 & $N R$ & \multirow[t]{2}{*}{$\begin{array}{l}1 \% \text { vs } 19 \% \mathrm{G} 3 / 4 \\
\text { diarrhoea, } 0 \text { vs } 8 \% \\
\text { G3/4 rash }\end{array}$} \\
\hline & & & $\begin{array}{l}\text { Lapatinib + } \\
\text { taxane }\end{array}$ & & & 75.8 & $9.1 *$ & $N R$ & \\
\hline \multirow[t]{2}{*}{$\begin{array}{l}\text { GUAN ET AL } \\
(2013)^{46}\end{array}$} & \multirow[t]{2}{*}{ III } & \multirow[t]{2}{*}{ Ist line } & $\begin{array}{l}\text { Lapatinib + } \\
\text { taxane }\end{array}$ & \multirow[t]{2}{*}{ Nil } & \multirow[t]{2}{*}{444} & 69 & 9.7 & 27.8 & \multirow[t]{2}{*}{$\begin{array}{l}23 \% \text { vs }<1 \% \text { G3 } \\
\text { diarrhoea }\end{array}$} \\
\hline & & & Placebo + taxane & & & $50 *$ & $6.5^{*}$ & $20.5^{*}$ & \\
\hline \multirow{2}{*}{$\begin{array}{l}\text { NEfERT, } \\
\text { AWADA ET } \\
\text { AL }(2016)^{74}\end{array}$} & \multirow[t]{2}{*}{ II } & \multirow[t]{2}{*}{ Ist line } & $\begin{array}{l}\text { Neratinib + } \\
\text { taxane }\end{array}$ & \multirow[t]{2}{*}{ Nil } & \multirow[t]{2}{*}{479} & 74.8 & 12.9 & $N R$ & \multirow{2}{*}{$\begin{array}{l}30.4 \% \text { vs } 3.8 \% \text { G3 } \\
\text { diarrhoea } \\
\text { No loperamide } \\
\text { prophylaxis allowed }\end{array}$} \\
\hline & & & $\begin{array}{l}\text { Trastuzumab }+ \\
\text { taxane }\end{array}$ & & & 77.6 & 12.9 & NR & \\
\hline \multirow[t]{2}{*}{$\begin{array}{l}\text { EGFI00I5I, } \\
\text { GEYER ET AL } \\
(2006)^{48}\end{array}$} & \multirow[t]{2}{*}{ III } & \multirow[t]{2}{*}{$\begin{array}{l}\geq 2 \mathrm{nd} \\
\text { line }\end{array}$} & $\begin{array}{l}\text { Lapatinib + } \\
\text { capecitabine }\end{array}$ & \multirow[t]{2}{*}{$\begin{array}{l}\text { Trastuzumab, } \\
\text { anthracycline + } \\
\text { taxane }\end{array}$} & \multirow[t]{2}{*}{324} & 22 & 8.4 & 75.0 weeks & \multirow[t]{2}{*}{$\begin{array}{l}\text { I2\% vs } 11 \% \text { G3 } \\
\text { diarrhoea, } 7 \text { vs II\% } \\
\text { G3 PPE }\end{array}$} \\
\hline & & & Capecitabine & & & $14 *$ & $4.1 *$ & 64.7 weeks & \\
\hline \multirow[t]{2}{*}{$\begin{array}{l}\text { MARTIN ET } \\
\operatorname{AL}(2013)^{66}\end{array}$} & \multirow[t]{2}{*}{ II } & \multirow[t]{2}{*}{$\begin{array}{l}\geq 2 \text { nd } \\
\text { line }\end{array}$} & Neratinib & \multirow{2}{*}{$\begin{array}{l}\text { I00\% previous } \\
\text { taxane (neo (adj) } \\
\text { or met) } \\
\text { I-2 lines } \\
\text { previous } \\
\text { trastuzumab }\end{array}$} & \multirow[t]{2}{*}{233} & 29 & 4.4 & 19.7 & \multirow{2}{*}{$\begin{array}{l}28 \% \text { vs } 10 \% \text { G } 3 / 4 \\
\text { diarrhoea } \\
\text { No neratinib- } \\
\text { associated LVEF drop }\end{array}$} \\
\hline & & & $\begin{array}{l}\text { Lapatinib + } \\
\text { capecitabine }\end{array}$ & & & $41^{*}$ & 6.8 & 23.6 & \\
\hline \multirow[t]{2}{*}{$\begin{array}{l}\text { SAURA ET AL } \\
(2014)^{69}\end{array}$} & \multirow[t]{2}{*}{ II } & \multirow[t]{2}{*}{$\begin{array}{l}\geq 2 \text { nd } \\
\text { line }\end{array}$} & $\begin{array}{l}\text { Neratinib + } \\
\text { capecitabine } \\
\text { (lapatinib naïve) }\end{array}$ & \multirow{2}{*}{$\begin{array}{l}100 \% \text { previous } \\
\text { taxane (neo (adj) } \\
\text { or met) } \\
\text { At least I prior } \\
\text { trastuzumab- } \\
\text { containing } \\
\text { regimen }\end{array}$} & \multirow[t]{2}{*}{105} & 64 & 40.3 weeks & NR & $\begin{array}{l}23 \% \text { G3 diarrhoea } \\
\text { (88\% all grades) No } \\
\text { loperamide }\end{array}$ \\
\hline & & & $\begin{array}{l}\text { Neratinib + } \\
\text { capecitabine } \\
\text { (lapatinib } \\
\text { exposed) }\end{array}$ & & & 57 & 35.9 weeks & NR & $\begin{array}{l}12 \% \text { experienced G3 } \\
\text { PPE }\end{array}$ \\
\hline $\begin{array}{l}\text { EMILIA, } \\
\text { VERMA ET AL }\end{array}$ & III & 2nd line & T-DMI & $\begin{array}{l}100 \% \text { prior } \\
\text { trastuzumab + }\end{array}$ & 991 & 44 & 9.6 & 30.9 & $\begin{array}{l}41 \% \text { vs } 57 \% \text { all G } 3 / 4 \\
\text { toxicities }\end{array}$ \\
\hline & & & $\begin{array}{l}\text { Lapatinib + } \\
\text { capecitabine } \\
\text { (lap/cape) }\end{array}$ & No pertuzumab & & $31^{*}$ & $6.4^{*}$ & $25.1 *$ & $\begin{array}{l}\text { T-DMI higher risk of } \\
\text { thrombocytopenia }+ \\
\text { abnormal LFTs }\end{array}$ \\
\hline $\begin{array}{l}\text { LUX-BREAST } \\
\text { I, HARBECK } \\
\text { ET AL } \\
(2016)^{28}\end{array}$ & III & $\begin{array}{l}\geq 2 n d \\
\text { line }\end{array}$ & $\begin{array}{l}\text { Afatinib + } \\
\text { vinorelbine }\end{array}$ & $\begin{array}{l}\text { Prior } \\
\text { trastuzumab in } \\
\text { the adjuvant or } \\
\text { Ist line }\end{array}$ & 508 & 46 & 5.5 & 20.5 & $\begin{array}{l}\text { Recruitment stopped } \\
\text { early due to safety } \\
\text { concerns with afatinib } \\
+ \text { vinorelbine }\end{array}$ \\
\hline & & & $\begin{array}{l}\text { Trastuzumab + } \\
\text { vinorelbine }\end{array}$ & & & 47 & 5.6 & $28.6 *$ & \\
\hline $\begin{array}{l}\text { NALA, } \\
\text { SAURA ET AL } \\
(2020)^{70}\end{array}$ & III & 3rd line & $\begin{array}{l}\text { Neratinib + } \\
\text { capecitabine }\end{array}$ & $\begin{array}{l}\text { 75\% previous } \\
\text { T-DMI }\end{array}$ & 621 & 32.8 & 5.6 & 21 & $\begin{array}{l}24 \% \text { vs } 12.5 \% \text { G3 } \\
\text { diarrhoea despite } \\
\text { loperamide }\end{array}$ \\
\hline & & & $\begin{array}{l}\text { Lapatinib + } \\
\text { capecitabine }\end{array}$ & $\begin{array}{l}42.5 \% \\
\text { trastuzumab + } \\
\text { pertuzumab }\end{array}$ & & 26.7 & $5.5^{*}$ & 18.7 & \\
\hline
\end{tabular}

(Continued) 
Table I (Continued).

\begin{tabular}{|c|c|c|c|c|c|c|c|c|c|}
\hline Trial & Phase & Setting & Arms & $\begin{array}{l}\text { Previous } \\
\text { Treatment }\end{array}$ & $\mathbf{N}$ & $\begin{array}{l}\text { ORR } \\
\text { (\%) }\end{array}$ & $\begin{array}{l}\text { Median PFS } \\
\text { (Months) }\end{array}$ & $\begin{array}{l}\text { Median OS } \\
\text { (Months) }\end{array}$ & Safety Profile \\
\hline \multirow[t]{2}{*}{$\begin{array}{l}\text { HER2CLIMB, } \\
\text { MURTHY ET } \\
\text { AL }(2020)^{83}\end{array}$} & \multirow[t]{2}{*}{ II } & \multirow[t]{2}{*}{ 3rd line } & $\begin{array}{l}\text { Trastuzumab + } \\
\text { capecitabine + } \\
\text { tucatinib }\end{array}$ & \multirow[t]{2}{*}{$\begin{array}{l}\text { I00\% previous } \\
\text { T-DMI + } \\
\text { trastuzumab/ } \\
\text { pertuzumab }\end{array}$} & \multirow[t]{2}{*}{612} & 40.6 & 7.8 & 21.9 & \multirow{2}{*}{$\begin{array}{l}12.9 \% \text { vs } 8.5 \% \text { G3 } \\
\text { diarrhoea with no } \\
\text { loperamide } \\
\text { prophylaxis } \\
5 \% \text { vs } 0.5 \% \text { G } 3 \\
\text { transaminitis }\end{array}$} \\
\hline & & & $\begin{array}{l}\text { Trastuzumab + } \\
\text { capecitabine }+ \\
\text { placebo }\end{array}$ & & & $22.8^{*}$ & $5.68^{*}$ & $17.4^{*}$ & \\
\hline \multirow[t]{2}{*}{$\begin{array}{l}\text { MA ET AL } \\
(2019)^{103}\end{array}$} & \multirow[t]{2}{*}{ ॥ } & \multirow[t]{2}{*}{ 3rd line } & $\begin{array}{l}\text { Pyrotinib + } \\
\text { capecitabine }\end{array}$ & \multirow{2}{*}{$\begin{array}{l}\text { Only } 29.7 \% \\
\text { received prior } \\
\text { anti-HER2 } \\
\text { therapy }\end{array}$} & \multirow[t]{2}{*}{128} & 78.5 & 18.1 & NR & \multirow{2}{*}{$\begin{array}{l}24.6 \% \text { vs } 20.6 \% \text { G3 } \\
\text { PPE } \\
\begin{array}{l}15.4 \% \text { vs } 4.8 \% \text { G3 } \\
\text { diarrhoea }\end{array}\end{array}$} \\
\hline & & & $\begin{array}{l}\text { Lapatinib + } \\
\text { capecitabine }\end{array}$ & & & $57.1^{*}$ & $7 *$ & NR & \\
\hline \multirow[t]{2}{*}{$\begin{array}{l}\text { PHOEBE, XU } \\
\text { ET AL (2020 } \\
\text { INTERIM) }^{104}\end{array}$} & \multirow[t]{2}{*}{ III } & \multirow[t]{2}{*}{$3 r d$ line } & $\begin{array}{l}\text { Pyrotinib + } \\
\text { capecitabine }\end{array}$ & \multirow{2}{*}{$\begin{array}{l}100 \% \text { received } \\
\text { trastuzumab }+ \\
\text { taxane } \\
\text { Maximum } 2 \text { lines } \\
\text { of chemo }\end{array}$} & \multirow[t]{2}{*}{267} & 67.2 & 12.5 & Not reached & \multirow[t]{2}{*}{$\begin{array}{l}30.6 \% \text { vs } 8.3 \% \mathrm{G} 3 \\
\text { diarrhoea }\end{array}$} \\
\hline & & & $\begin{array}{l}\text { Lapatinib + } \\
\text { capecitabine }\end{array}$ & & & $51.5^{*}$ & $6.8^{*}$ & Not reached & \\
\hline \multirow{2}{*}{$\begin{array}{l}\text { EFG I04900, } \\
\text { BLACKWELL } \\
\text { ET AL } \\
(2010)^{44}\end{array}$} & \multirow[t]{2}{*}{ III } & \multirow[t]{2}{*}{$\begin{array}{l}>3 r d \\
\text { line }\end{array}$} & $\begin{array}{l}\text { Lapatinib + } \\
\text { trastuzumab }\end{array}$ & $\begin{array}{l}100 \% \text { prior } \\
\text { trastuzumab }\end{array}$ & \multirow[t]{2}{*}{296} & 10.3 & 12.1 weeks & 14 & \multirow{2}{*}{$\begin{array}{l}\text { Asymptomatic } \\
\text { cardiac events: } 3.4 \% \\
\text { vs } 1.4 \% \\
\text { Symptomatic: } 2 \% \text { vs } \\
0.7 \%\end{array}$} \\
\hline & & & Lapatinib & $\begin{array}{l}\text { No T-DMI or } \\
\text { pertuzumab }\end{array}$ & & 6.9 & $8.1^{*}$ weeks & $9.5^{*}$ & \\
\hline
\end{tabular}

Notes: Emboldened arm includes tyrosine kinase inhibitor, *Indicates statistical significance.

Abbreviations: G3/G4, grade 3/grade 4; LFT, liver function test; LVEF, left ventricular ejection fraction; N, number of patients; NR, not reported; ORR, overall response rate; PFS, progression-free survival; OS, overall survival; PPE, palmo-plantar erythrodysesthesia.

The majority of lapatinib studies were conducted in the era prior to pertuzumab and T-DM1, therefore its efficacy for contemporary HER2+ MBC patients pre-treated with these agents is less established. However, a retrospective case series $(n=520)$ evaluating the impact of prior T-DM1 and pertuzumab on patients who received lapatinib, suggested that benefit from lapatinib is maintained in T-DM1 and pertuzumab pre-treated patients, with a clinical benefit rate (CBR) of $28 \%$ compared to $41 \%$ in those not exposed. ${ }^{54}$

\section{Lapatinib in CNS Disease}

Lapatinib was the first anti-HER2 agent to be validated in a pre-clinical setting as having direct anti-tumour activity against the development of CNS metastases; in this murine model, lapatinib reduced the formation of large brain metastases by $50 \%{ }^{55}$ Critically, it was demonstrated that lapatinib targeted only HER2+ brain metastases and not normal brain tissue. ${ }^{56}$ A retrospective analysis of the phase 3 EGFR100151 study showed a non-significant reduction in the risk of CNS disease as the first site of relapse for the capecitabine/lapatinib arm $(6.8$ vs $2.5 \%, p=0.1) .^{48}$
Supporting these results, a phase II study reported that the addition of capecitabine to lapatinib monotherapy increased the CNS ORR from $6 \%$ to $20 \%$ in a population of HER2+ MBC patients previously exposed to cranial radiotherapy and trastuzumab. ${ }^{57}$ This response was later confirmed in a randomised trial comparing capecitabine/lapatinib with topotecan/lapatinib, achieving a final CNS ORR of $38.5 \%$ for the lapatinib/capecitabine combination following radiotherapy. ${ }^{58}$

The CNS efficacy of lapatinib/capecitabine was also investigated in HER2+ MBC patients with untreated active brain metastases in the pioneering LANDSCAPE trial. Forty-five patients were enrolled in this single-arm phase 2 trial designed to assess the intracranial response rate, defined as a $50 \%$ or greater volumetric reduction in the absence of progressive steroid requirements, neurological symptoms or extracranial disease. The majority of patients had received prior trastuzumab (adjuvant or metastatic setting) and none had received prior cranial radiotherapy. The investigators reported an impressive CNS ORR of $65 \%$, with a median time to WBRT of 8.3 months, 
suggesting this combination could delay the need for invasive intervention. ${ }^{59}$ Unfortunately, $49 \%$ of the patients suffered G3-4 side effects, most commonly diarrhoea and hand-foot syndrome (HFS). ${ }^{59}$ Despite the proven intracranial efficacy for this combination, it failed to demonstrate superiority over trastuzumab and capecitabine in the prevention of symptomatic brain metastases in the CEREBEL (EGF111438) Phase III randomised trial, which was designed to assess the incidence of CNS disease as the first site of relapse in patients without CNS disease treated with lapatinib/capecitabine or trastuzumab/capecitabine. The CNS relapse rate was only $3 \%$ vs $5 \%$, respectively $(\mathrm{p}=0.36)$, at least in part due to baseline MRI screening for the study. ${ }^{60}$ This lower than expected incidence of CNS disease observed underpowered the study, which was prematurely terminated for futility, with interim data confirming no possibility of a meaningful conclusion with respect to the primary endpoint. PFS (HR 1.30, 95\% CI: 1.04 1.64) and OS (HR 1.34, 95\% CI: 0.95-1.64) were longer in the trastuzumab/capecitabine group, possibly a result of $44 \%$ of study participants being treated in the first line, ${ }^{60}$ which weighted the study in favour of trastuzumab with its known superiority to lapatinib in this setting. ${ }^{47}$ Table 2 outlines the major phase II/III studies which have assessed targeted TKIs for HER2+ MBC patients with CNS disease.

\section{Neratinib (HKI-272)}

Neratinib is a potent, irreversible, oral pan-HER TKI which blocks EGFR, HER2 and HER4, with similar potency at the EGFR and HER2 receptors, ${ }^{61,62}$ likely explaining the relatively higher burden of toxicity.

Pre-clinical studies demonstrated neratinib's potential to overcome both innate and acquired trastuzumab resistance in HER2+ breast cancer cell lines. ${ }^{63}$ Phase 1 evaluation concluded the maximum-tolerated dose (MTD) to be $240 \mathrm{mg}$ once daily, with grade 3-4 diarrhoea the significant DLT. ${ }^{64}$ A single-arm phase II trial which included both trastuzumab-naive $(n=70)$ and pre-treated patients $(n=66)$, reported an encouraging 54\% ORR in the first-line setting and $24 \%$ in trastuzumab-exposed patients. ${ }^{65}$ However, a randomised phase II trial, which optimistically compared neratinib monotherapy to capecitabine/lapatinib in patients who had received prior trastuzumab, failed to establish non-inferiority for PFS (median 4.5 months compared to 6.8 months, HR 1.19, 95\% CI 0.89-1.60), also reporting a numerically lower ORR of $29 \%$ for neratinib versus $41 \%$ with the standard doublet $(\mathrm{p}=0.067)$, and median OS (19.7 months versus 23.6 months), instead highlighting the risk of serious toxicity, with $28 \%$ of the patients who received neratinib experiencing G3-4 diarrhoea. ${ }^{66}$ Dual blockade in combination with trastuzumab in a chemotherapy-free regimen in has also been evaluated in a small phase I/II study $(n=45)$ in the trastuzumab-pre-treated setting; the recommended neratinib dose was the standard $240 \mathrm{mg}$, with grade 3 diarrhoea in $15.6 \%$ and modest efficacy reported, with a median PFS of 15.9 weeks; ${ }^{67}$ similar to that reported with neratinib monotherapy.

More encouragingly, an ORR of $63 \%$ was reported in a phase $1 \mathrm{~b}$ study $(\mathrm{n}=27)$ combining neratinib with T-DM1. The MTD of neratinib was $160 \mathrm{mg}$ neratinib combined with full dose $(3.6 \mathrm{mg} / \mathrm{kg})$ T-DM1, with grade 3 diarrhoea as the DLT in 6 patients. All patients who had all received trastuzumab, pertuzumab and a taxane, with responses at all neratinib doses evaluated. ${ }^{68}$ Patients found to have HER2 amplification in cfDNA (circulating free DNA) tended to endure more sustainable and durable responses to treatment with neratinib/T-DM1. The phase II study has completed accrual and its results are awaited.

Like its predecessor, neratinib eventually found its optimal efficacy in combination with capecitabine. Having established the MTD of capecitabine to be $1500 \mathrm{mg} / \mathrm{m}^{2}$ day $1-14$ of 21-day cycle alongside neratinib $240 \mathrm{mg}$ once daily continuously, a phase I/II study reported an ORR of $64 \%$ in the lapatinib-naïve population $(n=61)$ versus $57 \%$ in 4 patients who were lapatinib pretreated; all of whom had previously received a taxane and trastuzumab. ${ }^{69}$ The median PFS was 40.1 weeks and 35.9 weeks, respectively. Similarly, high rates of G3 diarrhoea were seen $(23 \%)$ to neratinib monotherapy in previous studies, but with low rates of treatment discontinuation $(5 \%)$ due to optimal management with dose reduction and loperamide, although anti-diarrhoeal prophylaxis was not mandated. ${ }^{69}$

The randomised phase 3 NALA trial was designed to evaluate capecitabine/neratinib compared to capecitabine/ lapatinib, with the primary endpoint of PFS. Neratinib and capecitabine modestly but statistically significantly prolonged median PFS to 6.6 from 8.8 months (HR 0.76, 95\% CI $0.63-0.93, \mathrm{p}=0.0059$ ) with 1 -year PFS rates of 28.8 versus $14.8 \% .^{70}$ The $32.8 \%$ ORR for capecitabine/ neratinib (95\% CI: 27.1-38.9, $\mathrm{p}=0.1201)$ was slightly lower than expected from the phase 2 studies but possibly relates to T-DM1 pre-treatment in $54 \%$ of patients and pertuzumab pre-treatment in $42 \%{ }^{70}$ Although median 
Table 2 Studies of Tyrosine Kinase Inhibitors in Advanced HER2-Positive Breast Cancer Patients with Brain Metastases

\begin{tabular}{|c|c|c|c|c|c|c|c|c|c|}
\hline Trial & Phase & Arms & $\begin{array}{l}\text { Previous } \\
\text { treatment of } \\
\text { brain } \\
\text { metastases }\end{array}$ & $\begin{array}{l}\text { Previous } \\
\text { Systemic } \\
\text { Treatment }\end{array}$ & $\begin{array}{l}\mathbf{N} \text { with } \\
\text { CNS } \\
\text { Disease }\end{array}$ & $\begin{array}{l}\text { CNS } \\
\text { ORR } \\
(\%)\end{array}$ & $\begin{array}{l}\text { CNS } \\
\text { Median } \\
\text { PFS } \\
\text { (Months) }\end{array}$ & $\begin{array}{l}\text { CNS } \\
\text { Median } \\
\text { OS } \\
\text { (Months) }\end{array}$ & Comments \\
\hline \multicolumn{10}{|l|}{ LAPATINIB } \\
\hline \multirow{2}{*}{$\begin{array}{l}\text { EGFI05084, } \\
\text { LIN ET AL } \\
(2009)^{57}\end{array}$} & \multirow{2}{*}{$\begin{array}{l}\text { II(two } \\
\text { phases) }\end{array}$} & Lapatinib & \multirow{2}{*}{$\begin{array}{l}100 \% \text { prior } \\
\text { cranial } \\
\text { radiotherapy }\end{array}$} & \multirow{2}{*}{$\begin{array}{l}100 \% \\
\text { trastuzumab }\end{array}$} & 240 & 6 & 2.4 & 6.37 & \multirow{2}{*}{$\begin{array}{l}\text { Only } 8 \% \text { expansion group } \\
\text { experienced G3 PPE }\end{array}$} \\
\hline & & $\begin{array}{l}\text { Lapatinib + } \\
\text { capecitabine } \\
\text { (expansion } \\
\text { phase) }\end{array}$ & & & 50 & 20 & 3.65 & NR & \\
\hline \multirow{2}{*}{$\begin{array}{l}\text { EGFI0767I, } \\
\text { LIN ET AL } \\
(20 \mathrm{II})^{58}\end{array}$} & \multirow[t]{2}{*}{ II } & $\begin{array}{l}\text { Lapatinib + } \\
\text { capecitabine }\end{array}$ & \multirow{2}{*}{$\begin{array}{l}100 \% \text { prior } \\
\text { cranial } \\
\text { radiotherapy }\end{array}$} & \multirow[t]{2}{*}{$\begin{array}{l}100 \% \\
\text { trastuzumab }\end{array}$} & \multirow[t]{2}{*}{22} & 38 & NR & NR & \multirow{2}{*}{$\begin{array}{l}\text { Stopped prematurely due to } \\
\text { lack of efficacy with } \\
\text { topotecan arm. Small sample } \\
\text { size. }\end{array}$} \\
\hline & & $\begin{array}{l}\text { Lapatinib + } \\
\text { topotecan }\end{array}$ & & & & 0 & NR & NR & \\
\hline \multirow{2}{*}{$\begin{array}{l}\text { EMILIA, } \\
\text { VERMA ET AL } \\
(2013)^{39}\end{array}$} & \multirow[t]{2}{*}{ III } & T-DMI & \multirow{2}{*}{$\begin{array}{l}100 \% \text { prior } \\
\text { cranial } \\
\text { radiotherapy }\end{array}$} & \multirow{2}{*}{$\begin{array}{l}100 \% \\
\text { trastuzumab } \\
\text { and taxane } \\
\text { chemotherapy }\end{array}$} & \multirow[t]{2}{*}{$95(\mathrm{AS})$} & NR & 5.9 & 26.8 & \multirow{2}{*}{$\begin{array}{l}\text { Exploratory analysis } \\
\text { therefore under-powered }\end{array}$} \\
\hline & & $\begin{array}{l}\text { Lapatinib + } \\
\text { capecitabine }\end{array}$ & & & & NR & 5.7 & $12.9 *$ & \\
\hline $\begin{array}{l}\text { LANDSCAPE, } \\
\text { BACHELOT } \\
\text { ETAL }(2013)^{59}\end{array}$ & $\begin{array}{l}\text { II } \\
\text { (single } \\
\text { arm) }\end{array}$ & $\begin{array}{l}\text { Lapatinib + } \\
\text { capecitabine }\end{array}$ & Nil & $\begin{array}{l}93 \% \\
\text { trastuzumab- } \\
\text { based } \\
\text { chemotherapy }\end{array}$ & 45 & 65.9 & 5.5 & 17 & $49 \%$ suffered G3/G4 toxicity \\
\hline \multicolumn{10}{|l|}{ AFATINIB } \\
\hline \multirow{3}{*}{$\begin{array}{l}\text { LUX-BREAST } \\
\text { I, HARBECK } \\
\text { ET AL }(2016)^{28}\end{array}$} & \multirow[t]{3}{*}{ II } & Afatinib & \multirow{3}{*}{$\begin{array}{l}75 \% \text { prior } \\
\text { cranial } \\
\text { radiotherapy }\end{array}$} & \multirow{3}{*}{$\begin{array}{l}100 \% \\
\text { trastuzumab } \\
80 \% \text { previous } \\
\text { lapatinib }\end{array}$} & \multirow[t]{3}{*}{111} & 0 & 11.9 & $\begin{array}{l}57.7 \\
\text { weeks }\end{array}$ & \multirow[t]{3}{*}{$\begin{array}{l}57 \% \text { G3 toxicity in afatinib + } \\
\text { vinorelbine group }\end{array}$} \\
\hline & & $\begin{array}{l}\text { Afatinib + } \\
\text { vinorelbine }\end{array}$ & & & & 8 & 12.3 & $\begin{array}{l}37.3 \\
\text { weeks }\end{array}$ & \\
\hline & & TPC & & & & 14 & 18.4 & $\begin{array}{l}52.1 \\
\text { weeks }\end{array}$ & \\
\hline \multicolumn{10}{|l|}{ NERATINIB } \\
\hline \multirow[t]{2}{*}{$\begin{array}{l}\text { TBCRC } 022, \\
\text { FREEDMAN } \\
\text { ET AL }(2019)^{75}\end{array}$} & \multirow[t]{2}{*}{$\begin{array}{l}\text { II } \\
\text { (single } \\
\text { arm) }\end{array}$} & \multirow[t]{2}{*}{$\begin{array}{l}\text { Neratinib }+ \\
\text { capecitabine }\end{array}$} & \multirow[t]{2}{*}{$\begin{array}{l}92 \% \text { prior } \\
\text { neurosurgery } \pm \\
\text { radiotherapy }\end{array}$} & $\begin{array}{l}\text { Cohort A: } \\
50 \% \text { exposed } \\
\text { to lapatinib }\end{array}$ & 49 & 49 & 5.5 & 13.3 & \multirow[t]{2}{*}{$\begin{array}{l}\text { Cohort B closed early due to } \\
\text { slow accrual }\end{array}$} \\
\hline & & & & $\begin{array}{l}\text { Cohort B: } \\
50 \% \text { lapatinib } \\
\text { naïve }\end{array}$ & & 33 & 3.1 & 15.1 & \\
\hline \multicolumn{10}{|l|}{ TUCATINIB } \\
\hline \multirow[t]{2}{*}{$\begin{array}{l}\text { HER2CLIMB, } \\
\text { MURTHY ET } \\
\text { AL }(2020)^{83}\end{array}$} & \multirow[t]{2}{*}{ II } & $\begin{array}{l}\text { Tucatinib }+ \\
\text { capecitabine }+ \\
\text { trastuzumab }\end{array}$ & \multirow[t]{2}{*}{$\begin{array}{l}43 \% \text { prior } \\
\text { cranial } \\
\text { radiotherapy }\end{array}$} & $\begin{array}{l}100 \% \\
\text { trastuzumab, } \\
\text { pertuzumab }\end{array}$ & 291 & 47.3 & 9.9 & 18.1 & $\begin{array}{l}\text { First TKI to demonstrate } \\
\text { significant OS benefit in } \\
\text { patients with CNS HER2+ }\end{array}$ \\
\hline & & $\begin{array}{l}\text { Placebo }+ \\
\text { capecitabine }+ \\
\text { trastuzumab }\end{array}$ & & and T-DMI & & $20 *$ & $4.2^{*}$ & $12 *$ & disease \\
\hline
\end{tabular}

Note: *Indicates statistical significance.

Abbreviations: AS, asymptomatic; CNS ORR, central nervous system overall response rate; CNS median OS, central nervous system median overall survival; CNS median PFS, central nervous system median progression-free survival; G3/G4, grade 3/grade 4; N, number of patients; NR, not reported; TPC, treatment of physician's choice. 
OS was numerically longer with capecitabine/neratinib (24.0 versus 22.2 months), a statistically significant benefit was not observed (HR 0.88, 95\% CI 0.972-1.07, $\mathrm{p}=0.286$ ). Despite the requirement for patients to use loperamide prophylaxis, $24 \%$ of patients in the neratinib arm experienced G3-4 diarrhoea, compared to $12.5 \%$ in the lapatinib arm, again highlighting the unpleasant EGFR-related toxicities. $^{70,71}$ Despite the additional toxicity with neratinib, health-related quality of life (QoL) was similar with neratinib and lapatinib. ${ }^{72}$

The management of neratinib-associated diarrhoea has been further clarified in the phase II CONTROL study which found that the addition of budesonide or colestipol throughout cycle 1 to regular prophylactic loperamide can reduce the risk of treatment discontinuation by $50 \%{ }^{73}$ A neratinib dose-escalation strategy (starting at $120 \mathrm{mg} /$ day days $1-7,160 \mathrm{mg}$ /day days 8-14 and $240 \mathrm{mg}$ /day thereafter) was also assessed to improve tolerability of neratinib without the addition of supportive medications. Although the data collection is still ongoing, the interim analysis for this cohort has demonstrated the lowest rates of G3 diarrhoea (15\%) and treatment discontinuation across all study arms. Furthermore, dose escalation substantially reduced the rates of constipation; from 57\% (loperamide arm) and 75\% (budesonide plus loperamide arm) to only $33 \%{ }^{73}$

Results of a phase 2 study combining neratinib with endocrine therapy (fulvestrant) in ER+ HER2+ MBC are awaited (NCT03289039).

\section{Neratinib in CNS Disease}

The phase II NEfERT study directly compared neratinib against trastuzumab in combination with paclitaxel in the first-line setting for HER2+ MBC. Although the neratinib arm was not superior to trastuzumab in terms of overall PFS, it did reduce the risk of CNS recurrence by $50 \%$, from $17.3 \%$ in the trastuzumab arm to $8.3 \%$ in the neratinib arm (HR 0.48, $\mathrm{P}=0.002){ }^{74}$ The risk of CNS progression was also lower in the neratinib arm (10.1 vs $20.2 \%$, HR $0.45, \mathrm{P}=0.004) .{ }^{74}$ Neratinib's apparent ability to control CNS disease was consistently observed across patients with and without baseline brain metastases. As previously, the neratinib/paclitaxel arm was associated with a $30 \%$ risk of G3-4 toxicities (versus only 4\% for trastuzumab/ paclitaxel), predominantly G3 diarrhoea. ${ }^{74}$

Although only patients with treated, stable brain metastases were included in the NALA study, notably fewer patients treated with neratinib required CNS intervention (22.8\% compared to $29.2 \%$ with capecitabine/lapatinib, $\mathrm{p}=0.043$ ), further confirming its superior CNS activity compared to lapatinib. ${ }^{70}$

The phase II TBCRC 022 study was specifically designed to evaluate the impact of capecitabine and neratinib in patients with HER2+ metastatic brain disease who had progressed after CNS-directed therapy (such as SRS, WBRT and/or surgery), stratified according to prior lapatinib exposure. The combination of capecitabine and neratinib proved to be highly efficacious with a CNS ORR of $49 \%(95 \% \mathrm{CI}, 32 \%$ to $66 \%)$ in patients who were lapatinib naïve and 33\% (95\% CI, $10 \%$ to $65 \%$ ) in lapatinib exposed. ${ }^{75}$ Once again, 30\% of patients experienced G3 diarrhoea despite the use of loperamide prophylaxis, causing $22 \%$ of patients in the lapatinib naïve group to discontinue treatment. $^{75}$ In summary, neratinib has impressive CNS activity for $\mathrm{MBC}$ patients able to tolerate the drug.

Unfortunately, the adjuvant phase III ExteNET study where a year of adjuvant neratinib following 12 months of trastuzumab was found to significantly prolong IDFS, neratinib did not significantly reduce the incidence of CNS recurrence over 5 years in comparison to placebo, although the number of events was very low in both arms ( $1.3 \%$ vs $1.8 \%, p=0.333)$, so it is difficult to draw any meaningful conclusions. ${ }^{76}$

\section{Tucatinib: (ARRY-380, ONT-380)}

Tucatinib is a highly selective, ATP-competitive, small molecule TKI with nanomolar potency for the HER2 receptor. $^{77}$ Cell-based assays have proven tucatinib to be 1000-fold more specific for HER2 over EGFR. ${ }^{77}$ In vitro models demonstrated that tucatinib powerfully blocks the phosphorylation of HER2 and its downstream effector, AKT3, in cell lines overexpressing HER2. In contrast, in EGFR-amplified cell lines, phosphorylation and proliferation were only weakly inhibited. ${ }^{78}$ Furthermore, tucatinib substantially inhibited the truncated form of HER2 in the setting of p95/p110 mutations, known to cause resistance to trastuzumab. ${ }^{8,78}$ In HER2+ murine xenograft models, tucatinib and its active metabolite exhibited superior CNS penetration and intracranial tumour activity in comparison to either neratinib or lapatinib. This translated to prolonged survival rates for the mice with intracranial HER2 + tumours who received tucatinib monotherapy. ${ }^{79}$

Tucatinib monotherapy was evaluated in a phase 1 dose-escalation study $(n=50)$ of patients, including an expansion cohort of 43 patients with HER2+ MBC. ${ }^{80}$ The patients were heavily pre-treated, with the majority 
having received prior trastuzumab and lapatinib, forming a representative population for the third-line setting. The most frequent dose-limiting toxicity was transaminitis, and at the MTD of $600 \mathrm{mg}$ twice daily, $19 \%$ of patients experienced G3-4 adverse effects which included rash, anaemia, hypokalaemia and transaminitis. ${ }^{80}$ The overall response rate and clinical benefit rate $(\mathrm{CBR}=\mathrm{SD}+\mathrm{PR})$ were reported at $14 \%$ and $27 \%$, respectively. These modest results compare somewhat unfavourably to that reported for neratinib monotherapy in the post-trastuzumab setting (ORR $24 \%$, CBR $33 \%){ }^{65}$ but only $5 \%(n=3 / 63)$ of patients had prior treatment with lapatinib. When lapatinib monotherapy was assessed in the phase 1 setting in a patient population who had all progressed on trastuzumab, its efficacy was limited with reported ORR and CBR of only $7.7 \%$ and $14.1 \%$, respectively. ${ }^{43}$

A phase 1 modified $3+3$ design dose-escalation study of a doublet comprising tucatinib combined with capecitabine, and then a triplet with the addition of trastuzumab was conducted in HER2+ MBC patients, all of whom had received prior trastuzumab, pertuzumab and T-DM1 ${ }^{81}$ The investigators' rationale for continuing trastuzumab beyond progression in the triplet arm stems from a growing body of clinical evidence that persistent antagonism of the HER2 receptor can improve outcome. Pre-clinical evaluation of tucatinib had demonstrated synergy when combined with trastuzumab in cell lines and mouse xenograft models. ${ }^{77}$ This concept of vertical blockade of the HER2 receptor (concurrent use of a monoclonal antibody and TKI) had been previously evaluated clinically with lapatinib plus trastuzumab in the EGF104900 phase 3 study which reported a significant benefit in both median OS (14 from 9.5 months, HR $0.74,95 \%$ CI $0.57-0.97$ $\mathrm{p}=0.026)$ and PFS (11.1 from 8.1 weeks, HR $0.75,95 \%$ CI $0.58-0.94, p=0.011)$ for trastuzumab and lapatinib vs lapatinib alone in a heavily pre-treated population, all of whom has previously progressed on trastuzumab. ${ }^{44}$ An exploratory analysis of the phase 3 GBG26/BIG 3-05 trial $(n=88)$ also reported a significant overall survival benefit for the re-introduction of trastuzumab to standard chemotherapy vs chemotherapy alone (median OS 18.8 vs 13.3 months, HR 0.63, $\mathrm{p}=0.02){ }^{82}$

Synergy of tucatinib combined with chemotherapy had also been demonstrated in pre-clinical work, although with docetaxel rather than with capecitabine. However, the combination of lapatinib plus capecitabine had led to approval and capecitabine plus trastuzumab has useful CNS activity, as demonstrated in the standard arm of the
CEREBEL study ${ }^{60}$ therefore the triplet regimen of tucatinib, trastuzumab and capecitabine was explored clinically.

The MTD for tucatinib was $300 \mathrm{mg}$ twice daily in combination with capecitabine $2000 \mathrm{mg} / \mathrm{m}^{2}$ days $1-14$ of 21-day cycle and trastuzumab $6 \mathrm{mg} / \mathrm{kg}$ IV every 3 weeks. Five of the 6 patients who received the doublet had a radiological response. The triplet demonstrated an encouraging ORR of $61 \%(14 / 23)$ with a median duration of response of 10 months. ${ }^{81}$ As hypothesised due to the minimal EGFR inhibition, the rate of G3-4 toxicity for the triplet was low at $15 \%$ with no clinically significant EGFR-related adverse events reported. ${ }^{81}$ These results were confirmed by the pivotal phase 2 placebocontrolled randomised HER2CLIMB trial which randomised (2:1) 612 patients to receive capecitabine and trastuzumab with either tucatinib or placebo. Prior treatment with trastuzumab, pertuzumab and T-DM1 was required and patients with active brain metastases were again permitted entry, making them a truly representative sample of HER2+ MBC patients today. ${ }^{83}$ The study met its primary endpoint, demonstrating improvement in 1-year PFS from $12.3 \%$ to $33.1 \%$ with tucatinib compared to placebo (HR 0.54, 95\% CI 0.42-0.71, $\mathrm{p}<0.001$ ). Tucatinib also reduced the risk of death by $34 \%$ compared to placebo, with a 2 -year OS of $45 \%$ versus $25 \%$ (HR $0.66,95 \%$ CI $0.50-0.77, \mathrm{P}=0.005$ ) and median OS of 21.9 versus 17.4 months. This benefit was observed across all subgroups including those with CNS disease (median PFS 7.6 versus 5.4 months and median OS of 18.1 vs 12 months). ${ }^{83}$ The experimental arm also achieved a useful ORR of $40.6 \%$ (vs $22.8 \%$ with placebo) in a population exposed to a median of three lines of treatment, advocating its potency in a resistant group of patients. ${ }^{83}$ The ORR of $22.8 \%$ in the capecitabine/trastuzumab/placebo arm mirrors the $20 \%$ ORR reported by the phase 2 single-arm trial $(n=40)$ which assessed the impact of capecitabine/trastuzumab in a heavily pre-treated HER2+ MBC population, all of whom has progressed on trastuzumab, an anthracycline and a microtubule inhibitor. ${ }^{84}$ HER2CLIMB adds further evidence that the doublet retains this moderate efficacy following T-DM1.

Importantly, the triplet remained well tolerated with only $12.9 \%$ of patients experiencing G3 diarrhoea (compared to $8.5 \%$ with placebo, without the requirement for anti-diarrhoeal prophylaxis) and 5.4\% G3 transaminitis $(0.5 \%$ with placebo), the majority of which were transient and reversible with appropriate dose reductions. The rate of treatment discontinuation due to adverse events was low 
at $5.7 \%$ with tucatinib ( $3 \%$ with placebo) and there was no evidence that tucatinib increased the risk of cardiac adverse events. $^{83}$ With FDA approval granted in April $2020,{ }^{85}$ this triplet is a very appealing option for post-TDM1 setting, including patients with CNS disease. In a sub-study of health-related QoL in the HER2CLIMB trial, no significant differences were seen between the treatment arms although QoL was maintained for longer in patients randomised to tucatinib. ${ }^{86}$ While tucatinib has proven its efficacy and tolerability, further information is required on its cost-effectiveness for the global population. A study carried out in 2020 assessed the cost-effectiveness of introducing tucatinib to trastuzumab and capecitabine in the Chinese and US populations using the data from HER2CLIMB: While the incremental cost-effectiveness ratios (ICERs) far exceeded the willingness to pay (WTP) threshold in both countries, it was much more favourable in those with brain metastases due to the more exaggerated difference in QALYs (quality adjusted life years). ${ }^{87}$

A second phase 1 study evaluated the combination of tucatinib with T-DM1, building on pre-clinical data showing synergy of tucatinib combined with two trastuzumab antibody-drug conjugates including T-DM1. ${ }^{88}$ The authors reported an MTD of tucatinib of $300 \mathrm{mg}$ bd combined with standard dose T-DM1 (3.6 mg/kg every 3 weeks) and no unexpected toxicity. A response rate of $47 \%$ and median PFS of 8.2 months was observed (95\% CI $4.8-10.3$ months), although this was reduced to 6.5 months $(95 \%$ CI, 4.1-9.2 months) in patients pre-treated with pertuzumab. ${ }^{89} \mathrm{~A}$ further randomised trial (HER2CLIMB02) will evaluate combination with T-DM1 in HER2+ MBC patients with and without brain metastases (Table 3).

Interim data from a phase $1 / 2$ study assessing the role of tucatinib combined with letrozole and the CDK4/6 inhibitor, palbociclib, in triple-positive MBC necessitated reduction of palbociclib to $75 \mathrm{mg} /$ day combined with tucatinib $300 \mathrm{mg}$ bd due to CYP3A interaction but reported a $31 \%$ response rate in women previously treated with trastuzumab and pertuzumab \pm T-DM1. ${ }^{90}$ A similar study of tucatinib combined with abemaciclib and trastuzumab (NCT 03846583) has been recently withdrawn.

\section{Tucatinib in CNS Disease}

Pre-clinical results, which have been presented but not published, reported an $80 \%$ reduction in brain phosphorylated HER2 and significantly higher survival rates in HER2+ breast cancer xenograft mouse models treated with tucatinib compared to those dosed with lapatinib or neratinib. $^{79}$ Consequently, patients with untreated and unstable ("active") brain metastases at baseline were included in the phase 1 study which informed the doses for the triplet used in the phase II HER2CLIMB study. An ORR of $42 \%$ was observed in those with active CNS disease receiving the triplet, with a median PFS of 6.7 months and a median duration of response of 10 months reported. ${ }^{81}$ The subsequent HER2CLIMB study was the first randomised placebo-controlled trial to demonstrate a significant PFS and OS benefit for patients with active CNS HER2+ disease, $43 \%$ of whom had not received prior CNS radiotherapy. The CNS-ORR for the tucatinib arm was significantly higher at $47.3 \%$ versus $20 \%$ in the placebo arm $(p=0.03) .{ }^{83}$ Tucatinib also significantly reduced the risk of intracranial progression by $68 \%$ (HR $0.32,95 \%$ CI, 0.22 to $0.48, \mathrm{P}<0.0001$ ) suggesting the PFS benefit observed in the overall study population was secondary to both improved extracranial and intracranial disease control. ${ }^{83}$ Additionally, the tucatinib arm also significantly reduced the risk of death by $42 \%$ in patients with CNS disease (median OS 18.1 vs 12 months, HR 0.58, 95\% CI, 0.40 to $0.85 \mathrm{p}=0.005$ ) compared to the placebo arm. ${ }^{83}$

An exploratory analysis of the patients with untreated or progressing brain metastases investigated whether the triplet combination delayed CNS intervention with radiotherapy and neurosurgery. In this group of patients $(n=174)$, median duration of CNS PFS was improved from 4.1 to 9.1 months, with a CNS-ORR of 47.3 vs $20.0 \%$ in the 75 patients with active brain metastases and measurable CNS disease. Furthermore, tucatinib allowed deferral of CNS radiotherapy in more patients with untreated metastases $(n=66)$, with prolonged PFS and OS in those randomised to tucatinib. ${ }^{83,91}$ Within the HER2CLIMB protocol, patients who developed isolated CNS progression were permitted to continue their blinded therapy after local treatment with surgery and radiotherapy. Thirty patients continued their treatment after isolated CNS progression and tucatinib was found to delay time to second CNS progression by 4.5 months (HR 0.33, $\mathrm{P}=0.02$ ) compared to placebo. ${ }^{91}$ As such, continuation of tucatinib in this setting is a reasonable strategy. Importantly, tucatinib also delays time to deterioration of QoL in patients with brain metastases. ${ }^{92}$

Patients with brain metastases $(n=30)$ were also entered in the phase 1 combination study with T-DM1, including 21 with active or untreated CNS disease. In patients with CNS disease, the median PFS was 6.7 months $(95 \%$ CI 
Table 3 Current Clinical Trials Looking at Tyrosine Kinase Inhibitors in Advanced HER2-Positive Breast Cancer

\begin{tabular}{|c|c|c|c|c|c|c|c|}
\hline $\begin{array}{l}\text { Trial } \\
\text { Identifier }\end{array}$ & Phase & $\begin{array}{l}\text { Treatment } \\
\text { Setting }\end{array}$ & Population & $\begin{array}{l}\text { Planned } \\
\text { Sample } \\
\text { Size }\end{array}$ & Treatment Arms & $\begin{array}{l}\text { Primary } \\
\text { Endpoint }\end{array}$ & $\begin{array}{l}\text { Study } \\
\text { Status }\end{array}$ \\
\hline \multicolumn{8}{|l|}{ TUCATINIB } \\
\hline $\begin{array}{l}\text { NCT03975647 } \\
\text { (HER2CLIMB- } \\
\text { 02) }\end{array}$ & $\begin{array}{l}\text { III (RCT } \\
\text { double blind) }\end{array}$ & 2nd line & HER2+ MBC & 460 & $\begin{array}{l}\text { Tucatinib + T-DMI vs } \\
\text { Placebo and T-DMI }\end{array}$ & PFS & Recruiting \\
\hline $\begin{array}{l}\text { NCT04539938 } \\
\text { (HER2CLIMB- } \\
\text { 04) }\end{array}$ & $\begin{array}{l}\text { II (single } \\
\text { arm) }\end{array}$ & $3 r d$ line & HER2+ MBC & 70 & Tucatinib + T-Dxd & ORR & Recruiting \\
\hline NCT03054363 & $\begin{array}{l}\text { Ib/ll (single } \\
\text { arm) }\end{array}$ & $\geq 3 r d$ line & $\begin{array}{l}\text { HR+ HER2+ } \\
\text { MBC }\end{array}$ & 42 & $\begin{array}{l}\text { Tucatinib, palbociclib + } \\
\text { letrozole }\end{array}$ & $\begin{array}{l}\text { Phase Ib: } \\
\text { incidence of } \\
\text { toxicity } \\
\text { Phase II: PFS }\end{array}$ & $\begin{array}{l}\text { Active, } \\
\text { not } \\
\text { recruiting }\end{array}$ \\
\hline NCT03501979 & $\begin{array}{l}\text { II (single } \\
\text { arm) }\end{array}$ & $\begin{array}{l}\text { No previous LMD } \\
\text { specific therapy }\end{array}$ & $\begin{array}{l}\text { HER2+ MBC } \\
\text { with } \\
\text { leptomeningeal } \\
\text { disease }\end{array}$ & 30 & $\begin{array}{l}\text { Tucatinib, trastuzumab }+ \\
\text { capecitabine }\end{array}$ & OS & Recruiting \\
\hline $\begin{array}{l}\text { NCT045 I 226I } \\
\text { (TOPAZ) }\end{array}$ & $\begin{array}{l}\mathrm{lb} / \mathrm{ll}(\text { single } \\
\mathrm{arm})\end{array}$ & $\geq$ Ist line & $\begin{array}{l}\text { HER2+ MBC } \\
\text { with brain } \\
\text { metastases } \\
\text { (new or } \\
\text { progression) }\end{array}$ & 33 & $\begin{array}{l}\text { Tucatinib, pembrolizumab + } \\
\text { trastuzumab }\end{array}$ & $\begin{array}{l}\text { Phase Ib: MTD } \\
\text { tucatinib (with } \\
\text { pembrolizumab } \\
\text { and trastuzumab) } \\
\text { Phase II: } 24 \text {-week } \\
\text { CNS DCR }\end{array}$ & $\begin{array}{l}\text { Not yet } \\
\text { recruiting }\end{array}$ \\
\hline $\begin{array}{l}\text { NCT0476043I } \\
\text { (HER2BRAIN) }\end{array}$ & $\begin{array}{l}\text { II (RCT } \\
\text { double blind) }\end{array}$ & $\begin{array}{l}\text { 2nd line } \\
\text { (progression on/ } \\
\text { after trastuzumab) }\end{array}$ & $\begin{array}{l}\text { HER2+ MBC } \\
\text { with active } \\
\text { brain } \\
\text { metastases }\end{array}$ & 120 & $\begin{array}{l}\text { Trastuzumab, taxane }+ \\
\text { pertuzumab vs trastuzumab, } \\
\text { taxane }+ \text { TKI (Tucatinib, } \\
\text { pyrotinib or neratinib) }\end{array}$ & CNS ORR & $\begin{array}{l}\text { Not yet } \\
\text { recruiting }\end{array}$ \\
\hline $\begin{array}{l}\text { NCT04538742 } \\
\text { (DESTINY- } \\
\text { BREAST07) }\end{array}$ & $\mathrm{Ib} / \mathrm{ll}$ & Ist line & $\begin{array}{l}\text { HER2+ MBC } \\
\text { including those } \\
\text { with active } \\
\text { brain } \\
\text { metastases }\end{array}$ & 350 & $\begin{array}{l}7 \text { cohorts combining T-DXd } \\
\text { with: } \\
\text { I) Durvalumab } \\
\text { 2) Pertuzumab } \\
\text { 3) Paclitaxel } \\
\text { 4) Durvalumab/paclitaxel } \\
\text { 5) T-DXd alone } \\
\text { 6) Tucatinib } \\
\text { 7) Tucatinib in active brain } \\
\text { mets } \\
\text { 8) T-DXd alone in active } \\
\text { brain mets }\end{array}$ & $\begin{array}{l}\text { Phase Ib/II: } \\
\text { incidence of } \\
\text { toxicity }\end{array}$ & Recruiting \\
\hline \multicolumn{8}{|l|}{ NERATINIB } \\
\hline NCT02673398 & $\begin{array}{l}\text { II (Single } \\
\text { arm) }\end{array}$ & $\geq 2$ nd line & $\begin{array}{l}\text { HER2 + MBC in } \\
\text { patients }>60\end{array}$ & 40 & Neratinib monotherapy & $\begin{array}{l}\text { Incidence of G2+ } \\
\text { toxicity }\end{array}$ & $\begin{array}{l}\text { Active, } \\
\text { not } \\
\text { recruiting }\end{array}$ \\
\hline NCT02236000 & $\begin{array}{l}\text { lb dose } \\
\text { escalation }+ \\
\text { II }\end{array}$ & 2nd line & HER2+ MBC & 63 & Neratinib + T-DMI & $\begin{array}{l}\text { Phase Ib: MTD } \\
\text { Phase II: ORR }\end{array}$ & $\begin{array}{l}\text { Active, } \\
\text { not } \\
\text { recruiting }\end{array}$ \\
\hline NCT03377387 & $\mathrm{Ib} / \mathrm{Il}$ & $\begin{array}{l}\text { Ib: any line } \\
\text { II: } \geq 2 \text { nd line }\end{array}$ & HER2+ MBC & 48 & Capecitabine $7 / 7+$ neratinib & Phase lb: MTD & Recruiting \\
\hline
\end{tabular}

(Continued) 
Table 3 (Continued).

\begin{tabular}{|c|c|c|c|c|c|c|c|}
\hline $\begin{array}{l}\text { Trial } \\
\text { Identifier }\end{array}$ & Phase & $\begin{array}{l}\text { Treatment } \\
\text { Setting }\end{array}$ & Population & $\begin{array}{l}\text { Planned } \\
\text { Sample } \\
\text { Size }\end{array}$ & Treatment Arms & $\begin{array}{l}\text { Primary } \\
\text { Endpoint }\end{array}$ & $\begin{array}{l}\text { Study } \\
\text { Status }\end{array}$ \\
\hline NCT03289039 & $\|$ & $\begin{array}{l}\text { 3rd line (must have } \\
\text { had prior } \\
\text { trastuzumab, } \\
\text { pertuzumab + } \\
\text { T-DMI) }\end{array}$ & $\begin{array}{l}\text { HR+ HER2+ } \\
\text { MBC }\end{array}$ & 21 & $\begin{array}{l}\text { Neratinib vs neratinib + } \\
\text { fulvestrant }\end{array}$ & PFS & $\begin{array}{l}\text { Active, } \\
\text { not } \\
\text { recruiting }\end{array}$ \\
\hline NCT0I494662 & $\begin{array}{l}\text { II ( } 4 \text { cohorts, } \\
\text { non- } \\
\text { randomised) }\end{array}$ & Varied & $\begin{array}{l}\text { HER2+ MBC } \\
\text { with brain } \\
\text { metastases }\end{array}$ & 168 & $\begin{array}{l}\text { I) Neratinib } \\
\text { 2) Neratinib + surgical } \\
\text { resection } \\
\text { 3) Neratinib + capecitabine } \\
\text { 4) Neratinib + T-DMI }\end{array}$ & CNS ORR & Recruiting \\
\hline \multicolumn{8}{|l|}{ PYROTINIB } \\
\hline $\begin{array}{l}\text { NCT03080805 } \\
\text { (PHOEBE) }\end{array}$ & III (RCT) & $\begin{array}{l}\geq 2 \text { nd line (must } \\
\text { have had prior } \\
\text { trastuzumab }+ \\
\text { taxane) }\end{array}$ & HER2+ MBC & 240 & $\begin{array}{l}\text { Pyrotinib + capecitabine vs } \\
\text { Lapatinib + capecitabine }\end{array}$ & PFS & $\begin{array}{l}\text { Active, } \\
\text { not } \\
\text { recruiting }\end{array}$ \\
\hline NCT02422199 & ॥ & $\begin{array}{l}\geq 2 \text { nd line (must } \\
\text { have had prior } \\
\text { trastuzumab }+ \\
\text { taxane, } \\
\text { anthracycline) }\end{array}$ & HER2+ MBC & 128 & $\begin{array}{l}\text { Pyrotinib + capecitabine vs } \\
\text { Lapatinib + capecitabine }\end{array}$ & Safety and ORR & Unknown \\
\hline NCT04246502 & $\begin{array}{l}\text { II } \\
\text { (randomised) }\end{array}$ & Ist line & HER2+ MBC & 200 & $\begin{array}{l}\text { Pyrotinib + capecitabine vs } \\
\text { Capecitabine }+ \text { trastuzumab } \\
+ \text { pertuzumab }\end{array}$ & PFS & $\begin{array}{l}\text { Not yet } \\
\text { recruiting }\end{array}$ \\
\hline NCT03876587 & $\begin{array}{l}\text { II (single } \\
\text { arm) }\end{array}$ & Ist line & HER2+ MBC & 79 & Pyrotinib + docetaxel & ORR & $\begin{array}{l}\text { Not yet } \\
\text { recruiting }\end{array}$ \\
\hline NCT03997539 & $\begin{array}{l}\text { Ib dose } \\
\text { escalation } \\
+ \text { II } \\
\text { (randomised) }\end{array}$ & $\begin{array}{l}\geq 2 \text { nd line (must } \\
\text { have had prior } \\
\text { trastuzumab + } \\
\text { taxane) }\end{array}$ & HER2+ MBC & 256 & $\begin{array}{l}\text { Pyrotinib + vinorelbine vs } \\
\text { TPC }\end{array}$ & $\begin{array}{l}\text { Phase Ib: MTD } \\
\text { Phase II: PFS }\end{array}$ & $\begin{array}{l}\text { Not yet } \\
\text { recruiting }\end{array}$ \\
\hline NCT0400I62I & $\begin{array}{l}\text { II (single } \\
\text { arm) }\end{array}$ & $\begin{array}{l}\geq 2 \text { nd line } \\
\text { (trastuzumab } \\
\text { resistance) }\end{array}$ & HER2+ MBC & 100 & Pyrotinib + capecitabine & PFS & Recruiting \\
\hline NCT04605575 & $\begin{array}{l}\text { lb dose } \\
\text { escalation + } \\
\text { II (single } \\
\text { arm) }\end{array}$ & $\begin{array}{l}\geq 2 \text { nd line (must } \\
\text { have had prior } \\
\text { trastuzumab }+ \\
\text { taxane) }\end{array}$ & HER2+ MBC & 208 & Pyrotinib + vinorelbine & $\begin{array}{l}\text { Phase Ib: MTD } \\
\text { Phase II: PFS }\end{array}$ & Recruiting \\
\hline NCT03863223 & $\begin{array}{l}\text { III (RCT, } \\
\text { double blind) }\end{array}$ & Ist line & HER2+ MBC & 590 & $\begin{array}{l}\text { Pyrotinib, trastuzumab + } \\
\text { docetaxel vs Placebo, } \\
\text { trastuzumab + docetaxel }\end{array}$ & PFS & Recruiting \\
\hline NCT03923I79 & $\begin{array}{l}\text { II (single } \\
\text { arm) }\end{array}$ & $\begin{array}{l}\geq 2 \text { nd line (must } \\
\text { have had prior } \\
\text { trastuzumab) }\end{array}$ & HER2+ MBC & 32 & Pyrotinib + etoposide & ORR & Recruiting \\
\hline $\begin{array}{l}\text { NCT04095390 } \\
\text { (INPHASE) }\end{array}$ & $\begin{array}{l}\text { II } \\
\text { (randomised) }\end{array}$ & $\begin{array}{l}\geq \text { Ist line (must } \\
\text { have had prior } \\
\text { trastuzumab) }\end{array}$ & $\begin{array}{l}\text { HR+ HER2+ } \\
\text { and HR- HER2+ } \\
\text { MBC }\end{array}$ & 60 & $\begin{array}{l}\text { HR+ HER2+ = pyrotinib, } \\
\text { SHR6390, letrozole } \\
\text { HR- HER2+ = pyrotinib, } \\
\text { SHR6390, capecitabine }\end{array}$ & ORR & Recruiting \\
\hline NCT04033I72 & $\begin{array}{l}\text { II (single } \\
\text { arm) }\end{array}$ & Ist line & $\begin{array}{l}\mathrm{HR}+\mathrm{HER} 2+ \\
\mathrm{MBC}\end{array}$ & 40 & Pyrotinib + fulvestrant & PFS & Recruiting \\
\hline
\end{tabular}


Table 3 (Continued).

\begin{tabular}{|c|c|c|c|c|c|c|c|}
\hline $\begin{array}{l}\text { Trial } \\
\text { Identifier }\end{array}$ & Phase & $\begin{array}{l}\text { Treatment } \\
\text { Setting }\end{array}$ & Population & $\begin{array}{l}\text { Planned } \\
\text { Sample } \\
\text { Size }\end{array}$ & Treatment Arms & $\begin{array}{l}\text { Primary } \\
\text { Endpoint }\end{array}$ & $\begin{array}{l}\text { Study } \\
\text { Status }\end{array}$ \\
\hline NCT04646759 & $\begin{array}{l}\text { III } \\
\text { (randomised) }\end{array}$ & $\geq 2$ nd line & $\begin{array}{l}\text { HR+ HER2+ } \\
M B C\end{array}$ & 516 & $\begin{array}{l}\text { Pyrotinib + capecitabine vs } \\
\text { Pyrotinib + fulvestrant }\end{array}$ & $\begin{array}{l}\text { PFS + incidence } \\
\text { of G3 PPE }\end{array}$ & Recruiting \\
\hline NCT039107I2 & $\begin{array}{l}\text { II } \\
\text { (randomised) }\end{array}$ & Ist line & $\begin{array}{l}\text { HR+ HER2+ } \\
M B C\end{array}$ & 250 & $\begin{array}{l}\text { Pyrotinib + trastuzumab }+\mathrm{Al} \\
\text { vs trastuzumab }+\mathrm{Al}\end{array}$ & PFS & $\begin{array}{l}\text { Not yet } \\
\text { recruiting }\end{array}$ \\
\hline NCT0369I05I & $\begin{array}{l}\text { II (single } \\
\text { arm) }\end{array}$ & Any line & $\begin{array}{l}\text { HER2+ MBC } \\
\text { with brain } \\
\text { metastases }\end{array}$ & 102 & Pyrotinib + capecitabine & CNS ORR & $\begin{array}{l}\text { Not yet } \\
\text { recruiting }\end{array}$ \\
\hline NCT03933982 & $\begin{array}{l}\text { II (single } \\
\text { arm) }\end{array}$ & $\begin{array}{l}\geq 2 \text { nd line (must } \\
\text { have had prior } \\
\text { taxane and } \\
\text { anthracycline) }\end{array}$ & $\begin{array}{l}\text { HER2+ MBC } \\
\text { with brain } \\
\text { metastases }\end{array}$ & 30 & Pyrotinib + vinorelbine & CNS ORR & Recruiting \\
\hline NCT04582968 & $\mid \mathrm{b} / \mathrm{II}$ & Any line & $\begin{array}{l}\text { HER2+ MBC } \\
\text { with brain } \\
\text { metastases }\end{array}$ & 47 & $\begin{array}{l}\text { Pyrotinib }+ \text { capecitabine }+ \\
\text { brain radiotherapy }\end{array}$ & $\begin{array}{l}\text { Phase Ib: } \\
\text { incidence of } \\
\text { toxicity } \\
\text { Phase II: } \\
\text { intracranial } \\
\text { progression }\end{array}$ & Recruiting \\
\hline NCT0463927I & $\begin{array}{l}\text { II (single } \\
\text { arm) }\end{array}$ & Any line & $\begin{array}{l}\text { HER2+ MBC } \\
\text { with brain } \\
\text { metastases }\end{array}$ & 100 & $\begin{array}{l}\text { Pyrotinib + trastuzumab + } \\
\text { abraxane }\end{array}$ & CNS ORR & $\begin{array}{l}\text { Not yet } \\
\text { recruiting }\end{array}$ \\
\hline \multicolumn{8}{|l|}{ POZIOTINIB } \\
\hline NCT026595I4 & $\begin{array}{l}\text { II (single } \\
\text { arm) }\end{array}$ & $\begin{array}{l}\text { 3rd line (must have } \\
\text { had previous } \\
\text { trastuzumab and } \\
\text { T-DMI) }\end{array}$ & HER2+ MBC & 67 & Poziotinib monotherapy & ORR & $\begin{array}{l}\text { Active, } \\
\text { not } \\
\text { recruiting }\end{array}$ \\
\hline \multicolumn{8}{|l|}{ LAPATINIB } \\
\hline NCT0I526369 & III (RCT) & Ist line & HER2+ MBC & 75 & $\begin{array}{l}\text { Lapatinib, trastuzumab }+ \\
\text { paclitaxel vs Trastuzumab }+ \\
\text { paclitaxel }\end{array}$ & PFS & $\begin{array}{l}\text { Active, } \\
\text { not } \\
\text { recruiting }\end{array}$ \\
\hline NCTOI873833 & $\begin{array}{l}\text { II (single } \\
\text { arm) }\end{array}$ & $\begin{array}{l}\geq 2 \text { nd line (must } \\
\text { have had prior } \\
\text { trastuzumab) }\end{array}$ & HER2+ MBC & 10 & $\begin{array}{l}\text { Capecitabine, } \\
\text { cyclophosphamide (PO), } \\
\text { lapatinib + trastuzumab }\end{array}$ & PFS & $\begin{array}{l}\text { Active, } \\
\text { not } \\
\text { recruiting }\end{array}$ \\
\hline NCT03500380 & $\begin{array}{l}\text { II } \\
\text { (randomised) }\end{array}$ & $\begin{array}{l}\geq 2 \text { nd line (must } \\
\text { have had prior } \\
\text { trastuzumab + } \\
\text { taxane) }\end{array}$ & HER2+ MBC & 228 & $\begin{array}{l}\text { RC48-ADC vs lapatinib + } \\
\text { capecitabine }\end{array}$ & PFS & Recruiting \\
\hline NCT00470704 & II (2 cohorts) & $\begin{array}{l}\text { Cohort I: Ist line } \\
\text { Cohort 2: } 2 \text { nd and } \\
\text { 3rd line }\end{array}$ & HER2+ MBC & 116 & Lapatinib + trastuzumab & ORR & $\begin{array}{l}\text { Active, } \\
\text { not } \\
\text { recruiting }\end{array}$ \\
\hline NCTOI273610 & $\begin{array}{l}\text { II (single } \\
\text { arm) }\end{array}$ & Any line & $\begin{array}{l}\text { HER2+ MBC } \\
\text { patients }>60\end{array}$ & 40 & Lapatinib + trastuzumab & $\begin{array}{l}\text { Incidence of G3+ } \\
\text { toxicity } \\
\text { +symptomatic } \\
\text { heart failure }\end{array}$ & $\begin{array}{l}\text { Active, } \\
\text { not } \\
\text { recruiting }\end{array}$ \\
\hline NCT0066725I & $\begin{array}{l}\text { III } \\
\text { (randomised) }\end{array}$ & Ist line & HER2+ MBC & 649 & $\begin{array}{l}\text { Lapatinib }+ \text { taxane vs } \\
\text { trastuzumab }+ \text { taxane }\end{array}$ & PFS & $\begin{array}{l}\text { Active, } \\
\text { not } \\
\text { recruiting }\end{array}$ \\
\hline
\end{tabular}

(Continued) 
Table 3 (Continued).

\begin{tabular}{|l|l|l|l|l|l|l|l|}
\hline $\begin{array}{l}\text { Trial } \\
\text { Identifier }\end{array}$ & Phase & $\begin{array}{l}\text { Treatment } \\
\text { Setting }\end{array}$ & Population & $\begin{array}{l}\text { Planned } \\
\text { Sample } \\
\text { Size }\end{array}$ & Treatment Arms & $\begin{array}{l}\text { Primary } \\
\text { Endpoint }\end{array}$ & $\begin{array}{l}\text { Study } \\
\text { Status }\end{array}$ \\
\hline NCT0I622868 & $\begin{array}{l}\text { II } \\
\text { (randomised) }\end{array}$ & $\begin{array}{l}\text { No previous cranial } \\
\text { radiotherapy }\end{array}$ & $\begin{array}{l}\text { HER2+ MBC } \\
\text { with brain } \\
\text { metastases }\end{array}$ & 143 & $\begin{array}{l}\text { WBRT or SRS vs WBRT or } \\
\text { SRS and lapatinib for 6 weeks }\end{array}$ & $\begin{array}{l}\text { CNS CR over I2 } \\
\text { weeks }\end{array}$ & $\begin{array}{l}\text { Active, } \\
\text { not } \\
\text { recruiting }\end{array}$ \\
\hline
\end{tabular}

Abbreviations: ADC, antibody-drug conjugate; Al, aromatase inhibitor; CR, complete response; DCR, disease control rate; G3, grade 3; HR+, hormone receptor positive; LMD, leptomeningeal disease; MBC, metastatic breast cancer; MTD, maximum tolerated dose; ORR, overall response rate; PFS, progression-free survival; PPE, palmo-plantar erythrodysesthesia; PO, oral; RCT, randomised controlled trial; SRS, stereotactic radiosurgery; TPC, treatment of physician's choice; WBRT, whole brain radiotherapy.

4.1-10.2 months) and the brain-specific response was 36\% amongst 14 evaluable patients with active CNS disease, ${ }^{89}$ comparable to but not obviously bettering the results with T-DM1 alone reported in the Kamilla trial. ${ }^{42}$ However, the results of HER2CLIMB-02 in this population will answer this question definitively.

CNS disease can also be a site of relapse after treatment for early HER2+ breast cancer. A meta-analysis of adjuvant trastuzumab demonstrated that the use of adjuvant trastuzumab was associated with a higher risk of CNS relapse than no treatment at all (HR 1.35, CI 1.02-1.78, $\mathrm{P}=0.038$ ), presumably due to excess extracranial relapses in patients not receiving adjuvant trastuzumab. ${ }^{93}$ Despite the significant improvement in relapse-free survival demonstrated in the adjuvant Katherine trial of T-DM1, ${ }^{94}$ the risk of developing brain metastases was not reduced, again likely reflecting limited CNS penetration. ${ }^{95}$ The CompassHER2 RD trial will evaluate the addition of tucatinib to adjuvant T-DM1 in patients without $\mathrm{pCR}$ after neo-adjuvant chemotherapy who are at clinically higher risk of CNS relapse (those with ER negative and/or residual node positive disease).

Ongoing studies of tucatinib in breast cancer are summarised in Table 3. Of particular note, patients with leptomeningeal disease were excluded from the HER2CLIMB trial, but a single-arm phase 2 study is recruiting patients with this poor prognosis site of disease to evaluate the tucatinib, trastuzumab and capecitabine triplet. Also, following pre-clinical synergy with anti-PDL-1 therapy demonstrated in mouse models, ${ }^{96}$ a planned combination study with pembrolizumab (TOPAZ, NCT04512261) in patients with HER2+ brain metastases has been developed.

What remains unknown about tucatinib, is whether it will be effective in patients who have progressed on lapatinib or neratinib. Efficacy in some patients who have progressed on lapatinib can reasonably be anticipated from tucatinib's greater anti-HER2 potency; a HER2
IC50 of $6.9 \mathrm{nmol} / \mathrm{L}$ compared to $109 \mathrm{nmol} / \mathrm{L}$ with lapatinib was reported in one kinase assay. Neratinib, however, has a very similar IC50 to tucatinib $(5.5 \mathrm{nmol} / \mathrm{L}){ }^{77}$ Furthermore, a more recent study reported (in abstract only) that neratinib was more potent than tucatinib in 4 out of 5 HER $2+$ breast cancer models. ${ }^{97}$

Cross-resistance for neratinib and tucatinib to the HER2 L755S mutation, a mechanism of acquired resistance to lapatinib, ${ }^{98}$ has been reported $;{ }^{99}$ therefore, tucatinib seems unlikely to be a useful option for patients who progress on lapatinib and subsequently show primary resistance to neratinib. In pre-clinical models, this resistance could be overcome by either T-DM1 or poziotinib, suggesting a possible future role for the experimental TKI in the post-tucatinib/neratinib setting. ${ }^{99}$

Of interest, a phase 1 dose-escalation study of tucatinib plus trastuzumab in 41 patients with HER $2+$ brain metastases, who had received a median of 2 prior treatments for $\mathrm{MBC}, 83 \%$ of whom had progressed after prior brain RT, reported only low rates of intracranial response $(12 \%$ of patients in the bd dosing cohort and only $6 \%$ in patients on the od dosing cohort). However, 15/41 patients experienced clinical benefit at 16 weeks, of whom 12 had received prior neratinib. ${ }^{100}$ These data are intriguing and suggest incomplete cross-resistance between the two drugs, but further clinical evaluation will be important.

\section{Experimental TKIs}

There are two further anti-HER2 TKIs in development predominantly in China, both of which have shown promising response rates in the HER2+ MBC setting. Both agents are irreversible pan-HER inhibitors and consequently, like neratinib, are laden with higher rates of EGFR-mediated toxicities. ${ }^{101,102}$ Their role so far is 
unclear as they are yet to be examined in patients who have all received trastuzumab, pertuzumab and T-DM1, making it difficult to extrapolate this data to the global population for consideration in the third-line setting.

\section{Poziotonib}

Unlike the majority of HER2-TKIs, poziotonib requires an intermittent dosing schedule (12 mg once daily days 1-14 of a 21-day cycle). A phase 1 monotherapy study included 75 patients with advanced breast cancer, amongst whom $60 \%$ experienced a partial response. As expected, most responses were in women with HER2+ cancers. ${ }^{30}$ The subsequent NOV120101-203 single-arm phase 2 trial assessed the efficacy of poziotonib in the third-line setting; although $99 \%$ had received trastuzumab and $94 \%$ received lapatinib, only $20 \%$ had been exposed to T-DM1 and $9 \%$ to pertuzumab. ${ }^{31}$ The trial reported an ORR of $25.5 \%$ and a PFS of 4.04 months (95\% CI: 2.94-4.40). ${ }^{31}$ However, patients were hampered by excessive rates of toxicity, with $96 \%$ and $92 \%$ of patients suffering from any grade of diarrhoea and stomatitis, respectively. ${ }^{31}$ A concerning $38 \%$ of patients experienced G3 diarrhoea which would preclude safe use of this agent in the clinical setting without a prophylactic supportive regimen proven to reduce toxicity. A subsequent US study in a predominantly Caucasian population investigated intermittent dosing at $24 \mathrm{mg}$ and $16 \mathrm{mg}$ reported very similar efficacy and toxicity results in a heavily pre-treated population. ${ }^{33}$

\section{Pyrotinib}

Pyrotinib is delivered on a continuous basis at an MTD of $400 \mathrm{mg}$ once a day with a major dose-limiting toxicity of diarrhoea. ${ }^{32}$ This study assessed the impact of pyrotinib in a population of HER2+ MBC patients heavily pre-treated with chemotherapy but only $66 \%$ exposed to prior trastuzumab. The ORR was $50 \%$ but this fell to $33.3 \%$ in patients previously exposed to trastuzumab. ${ }^{32}$

A randomised phase 2 trial has compared pyrotinib (400 mg once daily continuously) and capecitabine (2000 $\mathrm{mg} / \mathrm{m}^{2}$ days $1-14$ of 21-day cycle) with lapatinib (1250 mg once daily continuously) and capecitabine in a population previously treated with anthracyclines and taxanes (but only $29.7 \%$ exposed to prior anti-HER2 treatment). ${ }^{103}$ The primary endpoint of ORR for pyrotinib/capecitabine was an impressive 78.5\% (95\% CI: 68.5-88.5\%) versus $57.1 \%$ (95\% CI: 44.9-69.4\%) with lapatinib/capecitabine; the high response rates are likely explained by the low rates of exposure to trastuzumab. ${ }^{103}$ The pyrotinib/capecitabine combination also significantly improved PFS to 18.1 vs 7 months (HR $0.36,95 \%$ CI: $0.23-0.58, \mathrm{P}<0.001) .{ }^{103}$ Within the pyrotinib arm, $24 \%$ of patients experienced G3 hand-foot syndrome (HFS) and 15\% G3-4 diarrhoea but neither required discontinuation of pyrotinib. ${ }^{103}$ The randomised phase 3 PHOEBE trial evaluated the efficacy of second-line pyrotinib and capecitabine. Patients $(n=267)$ were required to have received prior trastuzumab and taxane, but prior pertuzumab was not obligatory. ${ }^{104}$ At the interim analysis, the pyrotinib arm was associated with a significantly longer PFS of 12.5 vs 6.8 months (HR 0.39 , 95\% CI: 0.27-0.56, $\mathrm{P}<0.0001)$ with the OS data still immature. ${ }^{104}$ Toxicity remained an issue, with G3-4 diarrhoea affecting a worrying $30.6 \%$ of patients randomised to the pyrotinib arm. ${ }^{104}$ While these data are evocative, the utility of this drug cannot be assured until further trials assess its efficacy after pertuzumab and T-DM1 and measures are in place to abrogate its excessive toxicity.

\section{Other 3rd Line (and Greater) Options}

The antibody-drug conjugate (ADCC) trastuzumab deruxtecan (DS-8201, T-DXd) has recently shown unprecedented results in heavily pre-treated advanced HER2+ breast cancer. The DESTINY-Breast 01 phase II trial demonstrated an impressive ORR of $60.9 \%$ (CI 53.4-68\%) in a group of HER2 + MBC patients with a median of six previous lines of treatment; this translated into a median PFS of 16.4 months (CI 12.7-NR). ${ }^{105}$ Updated results which have been presented but not published, reported a median PFS of 19.4 months and median OS of 24.6 months. ${ }^{106}$ Whilst these results are very evocative, $15.2 \%$ developed interstitial lung disease (ILD) and unfortunately, $2.7 \%$ died due to this treatment toxicity. ${ }^{106}$ The agent is also associated with moderate levels of grade 3 haematological toxicities as well as GI toxicities, which were mostly lower grade, but can be explained by the high drug-toantibody ratio, which is approximately double that of T-DM1. ${ }^{105}$ Early recognition and management of ILD can be reasonably expected to reduce this level of serious toxicity, but the results of ongoing phase 3 trials are required to confirm these data. An exploratory sub-group analysis of 24 patients with treated, stable CNS disease who were included in the study reported CNS progression in only $2 / 24$, plus $2 / 160$ patients without CNS disease at baseline. ${ }^{107}$ DESTINYBreast01 did not include patients with untreated brain metastases and therefore its efficacy in this population is unknown, 
but further studies are anticipated in this important sub-group. Large, randomised phase 3 studies will evaluate T-DXd in the 2nd (DESTINY-Breast03) and 3rd line (DESTINY-Breast02) settings compared to current standard regimens, and early phase studies will investigate novel combinations including immunotherapy (NCT04538742, NCT03523572). A phase 2 combination study of T-DXd with tucatinib is underway (HER2CLIMB-04), hopefully combining the significant efficacy seen with both new agents, which is an exciting prospect for HER2+ MBC patients (Table 3). At present, where available, this ADC represents a very valuable addition to the armoury for patients who have exhausted all standard antiHER2 therapies.

T-Dxd may also have a role in the HER2 low population (IHC $1+$ or 2+/FISH negative); a HER2 low expansion cohort within the dose-finding Phase I trial for T-DXd reported an ORR of $37 \%$ with a median duration of response of 10.4 months after a median of 7.5 lines of treatment. $^{108}$ The results of the randomised phase 3 DESTINY-Breast04 are therefore eagerly awaited.

\section{Conclusions}

We are now in the fortunate position to have several effective options available to our patients in the post T-DM1 setting, the sequencing of which will depend upon both drug availability and the needs of the individual patient.

While a multitude of studies have shown promising CNS response rates for first- and second-generation TKIs, particularly following compromise of the BBB and BTB with radiotherapy, tucatinib, in combination with capecitabine and trastuzumab, is the first TKI to provide a significant overall survival benefit for this population. This triplet regimen has therefore established itself as an efficacious and well-tolerated TKI for patients with metastatic HER2+ breast cancer who have progressed after the two lines of standard anti-HER2 therapy. Its proven efficacy for CNS disease, associated survival benefit and ability to delay CNS radiotherapy makes it an ideal candidate for the up to $50 \%$ of HER2+ MBC patients with this challenging site of disease.

It is our personal opinion that given the maintained efficacy of T-DXd in later lines of therapy, and the greater toxicity associated with the capecitabine/neratinib doublet, the third line standard of care for metastatic HER2+ breast cancer should, where available, be the combination of capecitabine, trastuzumab and tucatinib. However, clinicians may elect to utilise T-DXd earlier, especially for patients with rapidly progressive extracranial (but not intracranial) disease requiring an early response, particularly if in impending visceral crisis. In this case, given the higher response rate reported (60.9\% versus $40.6 \%$ ), T-DXd may be a preferred option, provided there is no history of interstitial lung disease. The comparable efficacy of capecitabine plus neratinib seen in the NALA trial and impressive response rate in CNS disease in TBCRC 022, makes this doublet, with anti-diarrhoeal prophylaxis, a useful alternative, especially where funding for the tucatinib-based triplet regimen is not available. Ongoing studies will determine both the optimal sequencing of the approved and newer agents, and, whether novel combinations of the ADCs and TKIs lead to better outcomes for our patients.

\section{Disclosure}

Dr Okines has participated in (compensated) advisory boards for Astra Zeneca/Daiichi Sankyo, Seagen and Roche, has received speakers fees from Pfizer, Roche and Seagen and has received research funding from Pfizer and Roche. The authors report no other conflicts of interest in this work.

\section{References}

1. Kreutzfeldt J, Rozeboom B, Dey N, De P. The trastuzumab era: current and upcoming targeted HER2+ breast cancer therapies. Am J Cancer Res. 2020;10:1045-1067.

2. Cesca MG, Vian L, Cristóvão-Ferreira S, Pondé N, de Azambuja E. HER2positive advanced breast cancer treatment in 2020. Cancer Treat Rev. 2020;88. doi:10.1016/j.ctrv.2020.102033

3. Slamon DJ, Clark GM, Wong SG, Levin WJ, Ullrich A, McGuire WL. Human breast cancer: correlation of relapse and survival with amplification of the HER-2/neu Oncogene.Science. 1987. Jan 9;235 (4785):177-82.doi:10.1126/science.3798106

4. Yao M, Fu P. Advances in anti-HER2 therapy in metastatic breast cancer. Chin Clin Oncol. 2018;7:1-9. doi:10.21037/cco.2018.05.04

5. Swain SM, Baselga J, Kim, SB, et al. Pertuzumab, trastuzumab, and docetaxel for HER2-positive metastatic breast cancer (CLEOPATRA): end-of-study results from a double-blind, randomised, placebo-controlled, phase 3 study. Lancet Oncol. 2020;21:519-530. doi:10.1016/S14702045(19)30863-0

6. Clynes RA, Towers TL, Presta LG, Ravetch JV. Inhibitory Fc receptors modulate in vivo cytotoxicity against tumor targets. Nat Med. 2000;6:443-446. doi:10.1038/74704

7. Slamon DJ, Leyland-Jones B, Shaket S, et al. Use of chemotherapy plus a monoclonal antibody against her2 for metastatic breast cancer that overexpresses HER2. N Engl J Med. 2001;344:783-792. doi:10.1056/NEJM200103153441101

8. Luque-Cabal M, García-Teijido P, Fernández-Pérez Y, SánchezLorenzo L, Palacio-Vázquez I. Mechanisms behind the resistance to trastuzumab in HER2-amplified breast cancer and strategies to overcome It. Clin Med Insights Oncol. 2016;10:21-30. doi:10.4137/CMO. S34537

9. Chumsri S, Sperinde J, Liu H, et al. High p95HER2/HER2 ratio associated with poor outcome in trastuzumab-treated HER2-positive metastatic breast cancer ncctg N0337 and NCCTG 98- 32-52(Alliance). Clin Cancer Res. 2018;24:3053-3058. doi:10.1158/1078-0432.CCR-17-1864 
10. Scaltriti M, Chandarlapaty S, Prudkin L, et al. Clinical benefit of lapatinib-based therapy in patients with human epidermal growth factor receptor 2-positive breast tumors coexpressing the truncated p95HER2 receptor. Clin Cancer Res. 2010;16:2688-2695. doi:10.1158/1078-0432.CCR-09-3407

11. Zhuang G, Brantley-Sieders DM, Vaught D, et al. Elevation of receptor tyrosine kinase EphA2 mediates resistance to trastuzumab therapy. Cancer Res. 2010;70:299-308. doi:10.1158/00085472.CAN-09-1845

12. Konecny GE, Pegram MD, Venkatesan N, et al. Activity of the dual kinase inhibitor lapatinib (GW572016) against HER-2-overexpressing and trastuzumab-treated breast cancer cells. Cancer Res. 2006;66:1630-1639. doi:10.1158/0008-5472. CAN-05-1182

13. Bendell JC, Domchek SM, Burstein HJ, et al. Central nervous system metastases in women who receive trastuzumab-based therapy for metastatic breast carcinoma. Cancer. 2003;97:2972-2977. doi:10.1002/cncr.11436

14. Bredin P, Walshe JM, Denduluri N. Systemic therapy for metastatic HER2-positive breast cancer. Semin Oncol. 2020. doi:10.1053/j.seminoncol.2020.07.008

15. Leone JP, Lin NU. Systemic therapy of central nervous system metastases of breast cancer. Curr Oncol Rep. 2019;21.

16. Terrell-Hall TB, Nounou MI, El-Amrawy F, Griffith JIG, Lockman PR. Trastuzumab distribution in an in-vivo and in-vitro model of brain metastases of breast cancer. Oncotarget. 2017;8:83734-83744. doi:10.18632/oncotarget.19634

17. Stemmler HJ, Schmitt, M, Willems, A, et al. Ratio of trastuzumab levels in serum and cerebrospinal fluid is altered in HER2-positive breast cancer patients with brain metastases and impairment of blood-brain barrier. Anticancer Drugs. 2007;18:23-28. doi:10.1097/01.cad.0000236313.50833.ee

18. Lin NU, Kumthekar P, Sahebjam S, et al. Abstract P1-18-03: pertuzumab $(\mathrm{P})$ plus high-dose trastuzumab $(\mathrm{H})$ for the treatment of central nervous system (CNS) progression after radiotherapy (RT) in patients (pts) with HER2-positive metastatic breast cancer (MBC): primary efficacy analysis results from the phase II PATRICIA study. Cancer Res. 2020. 80 P1-18-03-P1-18-03 (American Association for Cancer Research (AACR).

19. Mir O, Ropert S, Alexandre J, Lemare F, Goldwasser F. Highdose intrathecal trastuzumab for leptomeningeal metastases secondary to HER-2 overexpressing breast cancer. Ann Oncol. 2008;19:1978-1980. doi:10.1093/annonc/mdn654

20. Kordbacheh T, Law WY, Smith IE. Sanctuary site leptomeningeal metastases in HER-2 positive breast cancer: a review in the era of trastuzumab. Breast. 2016;26:54-58. doi:10.1016/j. breast.2015.11.005

21. Bonneau C, Paintaud G, Trédan O, et al. Phase I feasibility study for intrathecal administration of trastuzumab in patients with HER2 positive breast carcinomatous meningitis. Eur J Cancer. 2018;95:75-84. doi:10.1016/j.ejca.2018.02.032

22. Arvold ND,Lee EQ, Mehta MP, et al. Updates in the management of brain metastases. Neuro Oncol. 2016;18:1043-1065. doi:10.1093/neuonc/now127

23. Ramakrishna N, Temin S ,Chandarlapaty S, et al. Recommendations on disease management for patients with advanced human epidermal growth factor receptor 2-positive breast cancer and brain metastases: American Society of Clinical Oncology clinical practice guideline. J Clin Oncol. 2014;32:2100-2108. doi:10.1200/JCO.2013.54.0955

24. Brown PD, Ahluwalia MS, Khan OH, Asher AL, Wefel JS, Gondi V, et al. Whole-brain radiotherapy for brain metastases: evolution or revolution? J Clin Oncol. 2018;36:483-491. doi:10.1200/JCO.2017.75.9589
25. Cho E, Rubinstein L, Stevenson P, et al. The use of stereotactic radiosurgery for brain metastases from breast cancer: who benefits most? Breast Cancer Res Treat. 2015;149:743-749. doi:10.1007/s10549-014-3242-x

26. Vickers EP. A Beginner's Guide to Targeted Cancer Treatments. Wiley Blackwell; 2018.

27. Hartmann J, Haap M, Kopp H-G, Lipp H-P. Tyrosine kinase inhibitors - a review on pharmacology, metabolism and side effects. Curr Drug Metab. 2009;10:470-481. doi:10.2174/ 138920009788897975

28. Harbeck N, Huang CS, Hurvitz S, et al. Afatinib plus vinorelbine versus trastuzumab plus vinorelbine in patients with HER2-overexpressing metastatic breast cancer who had progressed on one previous trastuzumab treatment (LUX-Breast 1): an open-label, randomised, phase 3 trial. Lancet Oncol. 2016;17:357-366. doi:10.1016/S1470-2045(15)00540-9

29. Cortés J, Dieras V, RoetJ, et al. Afatinib alone or afatinib plus vinorelbine versus investigator's choice of treatment for HER2positive breast cancer with progressive brain metastases after trastuzumab, lapatinib, or both (LUX-Breast 3): a randomised, open-label, multicentre, phase 2 tr. Lancet Oncol. 2015;16:1700-1710. doi:10.1016/S1470-2045(15)00373-3

30. Kim TM, Lee KW, Oh DY, et al. Phase 1 studies of poziotinib, an irreversible pan-her tyrosine kinase inhibitor in patients with advanced solid tumors. Cancer Res Treat. 2018;50:835-842. doi:10.4143/crt.2017.303

31. Park YH, Lee, KH, Sohn JH, et al. A phase II trial of the pan-HER inhibitor poziotinib, in patients with HER2-positive metastatic breast cancer who had received at least two prior HER2-directed regimens: results of the NOV120101-203 trial. Int J Cancer. 2018;143:3240-3247. doi:10.1002/ijc.31651

32. Ma F, Li Q, ChenetS, et al. Phase I study and biomarker analysis of pyrotinib, a novel irreversible Pan-ERBB receptor tyrosine kinase inhibitor, in patients with human epidermal growth factor receptor 2-positive metastatic breast cancer. J Clin Oncol. 2017;35:3105-3112. doi:10.1200/JCO.2016.69.6179

33. Brufsky A, Zulfiqar M, Peguero J, et al. A phase 2 study of poziotinib in patients with HER2-positive metastatic breast cancer heavily pre-treated with HER2-targeted therapy. San Antonio Breast Cancer Symp. 2020. PD1-PD07.

34. Giordano SH, Temin S, Chandarlapaty S, et al. Systemic therapy for patients with advanced human epidermal growth factor receptor 2-positive breast cancer: American Society of Clinical Oncology clinical practice guideline. J Clin Oncol. 2014;32:2078-2099. doi:10.1200/JCO.2013.54.0948

35. Jiang H, Rugo HS. Human epidermal growth factor receptor 2 positive (HER2+) metastatic breast cancer: how the latest results are improving therapeutic options. Ther Adv Med Oncol. 2015;7:321-339. doi:10.1177/1758834015599389

36. Xuhong J-C, Qi X-W, Zhang Y, Jiang J. Mechanism, safety and efficacy of three tyrosine kinase inhibitors lapatinib, neratinib and pyrotinib in HER2-positive breast cancer. Am J Cancer Res. 2019;9:2103-2119.

37. Bachelot T, Ciruelos E, Schneeweiss A, et al. Preliminary safety and efficacy of first-line pertuzumab combined with trastuzumab and taxane therapy for HER2-positive locally recurrent or metastatic breast cancer (PERUSE). Ann Oncol. 2019;30:766-773. doi:10.1093/annonc/mdz061

38. Swain SM, Baselga J, Miles D, et al. Incidence of central nervous system metastases in patients with HER2-positive metastatic breast cancer treated with pertuzumab, trastuzumab, and docetaxel: results from the randomized phase III study CLEOPATRA. Ann Oncol. 2014;25:1116-1121. doi:10.1093/annonc/mdu133 
39. Verma S,Miles D, Gianni L, et al. Trastuzumab emtansine for HER2-positive advanced breast cancer. $N$ Engl $J$ Med. 2012;367:1783-1791. doi:10.1056/NEJMoa1209124

40. Krop IE, Kim SB, González-Martín A, et al. Trastuzumab emtansine versus treatment of physician's choice in patients with previously treated HER2-positive metastatic breast cancer (TH3RESA): final overall survival results from a randomised open-label phase 3 trial. Lancet Oncol. 2017;18:743-754. doi:10.1016/S1470-2045(17)30313-3

41. Perez EA, Barrios CH, Eiermann W, et al. Trastuzumab emtansine with or without pertuzumab versus trastuzumab plus taxane for human epidermal growth factor receptor 2-positive, advanced breast cancer: primary results from the phase III MARIANNE study. J Clin Oncol. 2017;35:141-148. doi:10.1200/JCO.2016.67.4887

42. Montemurro F,Delaloge S, Barrios $\mathrm{CH}$, et al. Trastuzumab emtansine (T-DM1) in patients with HER2-positive metastatic breast cancer and brain metastases: exploratory final analysis of cohort 1 from KAMILLA, a single-arm phase IIIb clinical trial. Ann Oncol. 2020;31:1350-1358. doi:10.1016/j.annonc.2020.06.020

43. Blackwell KL, Pegram MD, Tan-Chiu E, et al. Single-agent lapatinib for HER2-overexpressing advanced or metastatic breast cancer that progressed on first- or second-line trastuzumab-containing regimens. Ann Oncol. 2009;20:1026-1031. doi:10.1093/annonc/mdn759

44. Blackwell KL, Burstein HJ, Storniolo AM, et al. Overall survival benefit with lapatinib in combination with trastuzumab for patients with human epidermal growth factor receptor 2-positive metastatic breast cancer: final results from the EGF104900 study. J Clin Oncol. 2012;30:2585-2592. doi:10.1200/JCO.2011.35.6725

45. Giordano SH, Temin S, Chandarlapaty S, et al. Systemic therapy for patients with advanced human epidermal growth factor receptor 2 positive breast cancer: ASCO Clinical Practice Guideline Update. J Clin Oncol. 2018;36:2736-2740. doi:10.1200/JCO.2018.79.2697

46. Guan Z, Xu B, DeSilvio ML, et al. Randomized trial of lapatinib versus placebo added to paclitaxel in the treatment of human epidermal growth factor receptor 2-overexpressing metastatic breast cancer. J Clin Oncol. 2013;31:1947-1953. doi:10.1200/ JCO.2011.40.5241

47. Gelmon KA, Boyle FM, Kaufman B, et al. Lapatinib or trastuzumab plus taxane therapy for human epidermal growth factor receptor 2-positive advanced breast cancer: final results of NCIC CTG MA.31. J Clin Oncol. 2015;33:1574-1583. doi:10.1200/JCO.2014.56.9590

48. Geyer CE, Forster J, Lindquist D, et al. Lapatinib plus capecitabine for HER2-positive advanced breast cancer. $N$ Engl J Med. 2006;355:2733-2743. doi:10.1056/NEJMoa064320

49. Lousberg L, Collignon J, Jerusalem G. Resistance to therapy in estrogen receptor positive and human epidermal growth factor 2 positive breast cancers: progress with latest therapeutic strategies. Ther Adv Med Oncol. 2016;8:429-449. doi:10.1177/1758834016665077

50. Johnston S, Pippen Jr J ,PivotetX, et al. Lapatinib combined with letrozole versus letrozole and placebo as first-line therapy for postmenopausal hormone receptor - Positive metastatic breast cancer. J Clin Oncol. 2009;27:5538-5546. doi:10.1200/JCO.2009.23.3734

51. Johnston SRD, Hegg R, Im SA, et al. Phase III, randomized study of dual human epidermal growth factor receptor 2 (HER2) blockade with lapatinib plus trastuzumab in combination with an aromatase inhibitor in postmenopausal women with HER2-positive, hormone receptor-positive metastatic breast. J Clin Oncol. 2020. doi: $10.1200 /$ jco.20.01894

52. Rimawi M, Ferrero JM, Haba-Rodriguez, J, et al. First-line trastuzumab plus an aromatase inhibitor, with or without pertuzumab, in human epidermal growth factor receptor 2-positive and hormone receptor-positive metastatic or locally advanced breast cancer (PERTAIN): a randomized, open-label phase II trial. $J$ Clin Oncol. 2018;36:2826-2835. doi:10.1200/ JCO.2017.76.7863
53. Arpino G, Haba-Rodriguez J, Ferrero JM, et al. Final analysis of PERTAIN: a randomised, two-arm, open-label, multicenter phase II trial assessing the efficacy and safety of first-line pertuzumab given in combination with trastuzumab plus an aromatase inhibitor in patients with HER2-positive and hormone. San Antonio Breast Cancer Symp. 2020. PD02-PD3.

54. Baez-Vallecillo L, Raghavendra AS, Hesset KR, et al. Lapatinib activity in metastatic human epidermal growth factor receptor 2-positive breast cancers that received prior therapy with trastuzumab, pertuzumab, and/or ado-trastuzumab emtansine (T-DM1). Breast Cancer Res Treat. 2019;176:227-234. doi:10.1007/ s10549-018-05081-z

55. Gril B, Palmieri D, Bronder JL, et al. Effect of lapatinib on the outgrowth of metastatic breast cancer cells to the brain. $J$ Natl Cancer Inst. 2008;100:1092-1103. doi:10.1093/jnci/djn216

56. Saleem A, Searle GE, Kenny LM, et al. Lapatinib access into normal brain and brain metastases in patients with Her-2 overexpressing breast cancer. EJNMMI Res. 2015;5. doi:10.1186/ s13550-015-0103-5

57. Lin NU, Diéras V, Paul D, et al. Multicenter phase II study of lapatinib in patients with brain metastases from HER2-positive breast cancer. Clin Cancer Res. 2009;15:1452-1459. doi:10.1158/ 1078-0432.CCR-08-1080

58. Lin NU, Eierman W, GreiletR, et al. Randomized phase II study of lapatinib plus capecitabine or lapatinib plus topotecan for patients with HER2-positive breast cancer brain metastases. $J$ Neurooncol. 2011;105:613-620. doi:10.1007/s11060-0110629-y

59. Bachelot T, Romieu G, Campone MD, et al. Lapatinib plus capecitabine in patients with previously untreated brain metastases from HER2-positive metastatic breast cancer (LANDSCAPE): a single-group phase 2 study. Lancet Oncol. 2013;14:64-71. doi:10.1016/S1470-2045(12)70432-1

60. Pivot X, Manikhas A, Żurawski B, et al. CEREBEL (EGF111438): a phase III, randomized, open-label study of lapatinib plus capecitabine versus trastuzumab plus capecitabine in patients with human epidermal growth factor receptor 2-positive metastatic breast cancer. J Clin Oncol. 2015;33:1564-1573. doi:10.1200/JCO.2014.57.1794

61. Larionov AA. Current therapies for human epidermal growth factor receptor 2-positive metastatic breast cancer patients. Front Oncol. 2018;8. doi:10.3389/fonc.2018.00089

62. Rabindran SK, Discafani CM, Rosfjord EC, et al. Antitumor activity of HKI-272, an orally active, irreversible inhibitor of the HER-2 tyrosine kinase. Cancer Res. 2004;64:3958-3965. doi:10.1158/0008-5472.CAN-03-2868

63. Canonici A, Gijsen M, Mullooly M, et al. Neratinib overcomes trastuzumab resistance in HER2 amplified breast cancer. Oncotarget. 2013;4:1592-1605. doi:10.18632/oncotarget.1148

64. Ito Y, Suenaga M, Hatake K,et al. Safety, efficacy and pharmacokinetics of neratinib (HKI-272) in Japanese patients with advanced solid tumors: a phase 1 dose-escalation study. Jpn J Clin Oncol. 2012;42:278-286. doi:10.1093/jjco/hys012

65. Burstein HJ,Sun Y, Dirixet LY, et al. Neratinib, an irreversible ErbB receptor tyrosine kinase inhibitor, in patients with advanced ErbB2-positive breast cancer. J Clin Oncol. 2010;28:1301-1307. doi:10.1200/JCO.2009.25.8707

66. Martin M, Bonneterre J, Geyer CE, et al. A phase two randomised trial of neratinib monotherapy versus lapatinib plus capecitabine combination therapy in patients with HER2+ advanced breast cancer. Eur J Cancer. 2013;49:3763-3772. doi:10.1016/j.ejca.2013.07.142

67. Blackwell KL, Zaman K, Qin S, et al. Neratinib in combination with trastuzumab for the treatment of patients with advanced HER2-positive breast cancer: a Phase I/II study. Clin Breast Cancer. 2019;19:97-104.e4. doi:10.1016/j.clbc.2018.12.011 
68. Abraham J, Montero AJ, Jankowitz RC, et al. Safety and efficacy of T-DM1 plus neratinib in patients with metastatic HER2-positive breast cancer: NSABP Foundation Trial FB-10. $J$ Clin Oncol. 2019;37:2601-2609. doi:10.1200/JCO.19.00858

69. Saura C, Garcia-Saenz JA, Xu B, et al. Safety and efficacy of neratinib in combination with capecitabine in patients with metastatic human epidermal growth factor receptor 2-positive breast cancer. $J$ Clin Oncol. 2014;32:3626-3634. doi:10.1200/JCO.2014.56.3809

70. Saura C, Oliveira M, Feng Y-H, et al. Neratinib plus capecitabine versus lapatinib plus capecitabine in HER2-positive metastatic breast cancer previously treated with $\geq 2$ HER2-directed regimens: phase III NALA Trial. J. Clin. Oncol. 2020;38:3138-3149. doi:10.1200/JCO.20.00147

71. Oliveira M, Garrigós L, Assaf JD, Escrivá-de-romaní S, Saura C. Neratinib plus capecitabine for the treatment of advanced HER2-positive breast cancer. Expert Rev Anticancer Ther. 2020;00:1-11.

72. Moy B, Oliveira M, Saura C, et al. Neratinib + capecitabine sustains health-related quality of life (HRQoL) while improving progression-free survival (PFS) in patients with HER2+ metastatic breast cancer and $\geq 2$ prior HER2-directed regimens. San Antonio Breast Cancer Symp. 2020. PS9-PS02.

73. Barcenas CH, Hurvitz SA, Di Palma JA, et al. Improved tolerability of neratinib in patients with HER2-positive early-stage breast cancer: the CONTROL trial. Ann.Oncol. 2020;31:1223-1230. doi:10.1016/j.annonc.2020.05.012

74. Awada A, Colomer R, Inoue K, et al. Neratinib plus paclitaxel vs trastuzumab plus paclitaxel in previously untreated metastatic ERBB2-positive breast cancer the NEfERT-T randomized clinical trial. JAMA Oncol. 2016;2:1557-1564. doi:10.1001/ jamaoncol.2016.0237

75. Freedman RA, Gelman RS, Anders CK, et al. TBCRC 022: a phase II trial of neratinib and capecitabine for patients with human epidermal growth factor receptor 2-positive breast cancer and brain metastases. J Clin Oncol. 2019;37:1081-1089. doi:10.1200/JCO.18.01511

76. Martin M, Holmes FA, Ejlertsen B, et al. Neratinib after trastuzumab-based adjuvant therapy in HER2-positive breast cancer (ExteNET): 5-year analysis of a randomised, double-blind, placebo-controlled, phase 3 trial. Lancet Oncol. 2017;18:1688-1700.

77. Kulukian A, Lee P, Taylor J, et al. Preclinical activity of HER2-selective tyrosine kinase inhibitor tucatinib as a single agent or in combination with trastuzumab or docetaxel in solid tumor models. Mol Cancer Ther. 2020;19:976-987. doi:10.1158/ 1535-7163.MCT-19-0873

78. Pheneger TBouhana A, Anderson D, et al. Abstract \#1795: in Vitro and in vivo activity of ARRY-380: a potent, small molecule inhibitor of ErbB2. Cancer Res. 2009;69.

79. Dinkel VAnderson D, Winski S, et al. Abstract 852: ARRY-380, a potent, small molecule inhibitor of ErbB2, increases survival in intracranial ErbB2+ xenograft models in mice. Cancer Res. 2012;72:852.

80. Moulder SL, Borges VF, Baetz T, et al. Phase I Study of ONT-380, a HER2 Inhibitor, in Patients with HER2 +-Advanced Solid Tumors, with an Expansion Cohort in HER2 + Metastatic Breast Cancer (MBC). Clin Cancer Res. 2017;23:3529-3536. doi:10.1158/1078-0432.CCR-16-1496

81. Murthy R, Borges VF, Conlin A, et al. Tucatinib with capecitabine and trastuzumab in advanced HER2-positive metastatic breast cancer with and without brain metastases: a non-randomised, open-label, phase $1 \mathrm{~b}$ study. Lancet Oncol. 2018;19:880-888. doi:10.1016/S1470-2045(18)30256-0

82. Von Minckwitz G, Schwedler K, Schmidt M, et al. Trastuzumab beyond progression: overall survival analysis of the GBG 26/BIG 3-05 phase III study in HER2-positive breast cancer. Eur J Cancer. 2011;47:2273-2281. doi:10.1016/j.ejca.2011.06.021
83. Murthy RK, Loi S, Okines A, et al. Tucatinib, trastuzumab, and capecitabine for HER2-positive metastatic breast cancer. $N$ Engl $J$ Med. 2020;382:597-609. doi:10.1056/NEJMoa1914609

84. Bartsch R, Wenzel C, Altorjai G, et al. Capecitabine and trastuzumab in heavily pretreated metastatic breast cancer. $J$ Clin Oncol. 2007;25:3853-3858. doi:10.1200/JCO.2007.11.9776

85. Lee A. Tucatinib: first Approval. Drugs. 2020;80:1033-1038. doi:10.1007/s40265-020-01340-w

86. Mueller V, Paplomata E, Hamilton EP, et al. $275 \mathrm{O}$ Impact of tucatinib on health-related quality of life (HRQoL) in patients with HER2+ metastatic breast cancer (MBC) with and without brain metastases (BM). Ann Oncol. 2020;31:S349-S350. doi:10.1016/j.annonc.2020.08.377

87. Wu Q, Liao W, Zhang M, Huang J, Zhang P, Li Q. Costeffectiveness of tucatinib in human epidermal growth factor receptor 2-positive metastatic breast cancer from the US and Chinese perspectives. Front Oncol. 2020;10:1-11. doi:10.3389/ fonc. 2020.00001

88. Kulukian A, Taylor J, Olson D, et al. Abstract P1-18-09: tucatinib, a HER2-selective tyrosine kinase inhibitor, increases the anti-tumor activity of trastuzumab antibody-drug conjugates in preclinical models of HER2+ breast cancer. Cancer Res. 2020;80. P1-18-09-P1 -18-09 (American Association for Cancer Research (AACR).

89. Borges VF, Ferrario C, Aucoin N, et al. Tucatinib combined with ado-trastuzumab emtansine in advanced ERBB2/HER2 -positive metastatic breast cancer. JAMA Oncol. 2018;4:1214-1220. doi:10.1001/jamaoncol.2018.1812

90. Shagisultanova E, Chalasani P, Brown-Glaberman UA, et al. Tucatinib, palbociclib, and letrozole in HR+/HER2+ metastatic breast cancer: report of phase IB safety cohort. J Clin Oncol. 2019;37:1029. doi:10.1200/JCO.2019.37.15_suppl.1029

91. Lin NU, Borges V, Anders C, et al. Intracranial efficacy and survival with tucatinib plus trastuzumab and capecitabine for previously treated HER2-positive breast cancer with brain metastases in the HER2CLIMB trial. $J$ Clin Oncol. 2020;38:2610-2619. doi:10.1200/JCO.20.00775

92. Wardley A, Mueller V, Paplomata E, et al. Impact of tucatinib on health-related quality of life in patients with HER2+ metastatic breast cancer with stable and active brain metastases. San Antonio Breast Cancer Symp. 2020. PD04-PD13.

93. Olson EM, Abdel-Rasoul M, Maly J, et al. Incidence and risk of central nervous system metastases as site of first recurrence in patients with HER2-positive breast cancer treated with adjuvant trastuzumab. Ann Oncol. 2013;24:1526-1533. doi:10.1093/annonc/mdt036

94. von Minckwitz G, Huang C-S, Mano MS, et al. Trastuzumab emtansine for residual invasive HER2-positive breast cancer. N Engl J Med. 2019;380:617-628. doi:10.1056/NEJMoa1814017

95. Loibl S, Huang C-S, Mano MS, et al. 960 Adjuvant trastuzumab emtansine (T-DM1) vs trastuzumab (T) in patients (pts) with residual invasive disease after neoadjuvant therapy for HER2+ breast cancer: subgroup analysis from KATHERINE. Ann Oncol. 2020;31:S48. doi:10.1016/j.annonc.2020.03.036

96. Li R, Sant S, Brown E, et al. Tucatinib favourably modulates the immune microenvironment and synergises with anti-PD1 therapy in a trastuzumab resistant HER2+ murine model. San Antonio Breast Cancer Symp. 2020.

97. Conlon NTKooijman JJ, van Gerwen SJC, et al. Comparative analysis of anti-proliferative effects and gene profiling of lapatinib, neratinib, and tucatinib. San Antonio Breast Cancer Symp. 2020. PS10-PS06.

98. Xu X, De Angelis C, Burke KA, et al. HER2 reactivation through acquisition of the HER2 L755S mutation as a mechanism of acquired resistance to HER2-targeted therapy in HER2 + breast cancer. Clin Cancer Res. 2017;23:5123-5134. doi:10.1158/10780432.CCR-16-2191 
99. Veeraraghavan J, Mistry R, Nanda S, et al. HER2 L755S mutation is acquired upon resistance to lapatinib and neratinib and confers cross-resistance to tucatinib and trastuzumab in HER2-positive breast cancer cell models. San Antonio Breast Cancer Symp. 2020. PD3-PD09.

100. Metzger Filho O, Leone JP, Liet T, etal. Phase I dose-escalation trial of tucatinib in combination with trastuzumab in patients with HER2-positive breast cancer brain metastases. Ann Oncol. 2020;31:1231-1239. doi:10.1016/j.annonc.2020.05.014

101. Escrivá-de-romaní S, Arumí M, Bellet M, Saura C. HER2positive breast cancer: current and new therapeutic strategies. Breast. 2018;39:80-88. doi:10.1016/j.breast.2018.03.006

102. Kunte S, Abraham J, Montero AJ. Novel HER2-targeted therapies for HER2-positive metastatic breast cancer. Cancer. 2020;126:4278-4288. doi:10.1002/cncr.33102

103. Ma F, Ouyang Q, Li W, et al. Pyrotinib or lapatinib combined with capecitabine in HER2-positive metastatic breast cancer with prior taxanes, anthracyclines, and/or trastuzumab: a randomized, phase II study. J Clin Oncol. 2019;37:2610-2619. doi:10.1200/JCO.19.00108

104. Xu BYan M, Ma F, et al. Pyrotinib plus capecitabine versus lapatinib plus capecitabine for the treatment of HER2-positive metastatic breast cancer (PHOEBE): a multicentre, open-label, randomised, controlled, phase 3 trial. Lancet Oncol. 2021;22:351-360. doi:10.1016/S1470-2045(20)30702-6
105. Modi S,Saura C, Yamashita T, et al. Trastuzumab deruxtecan in previously treated HER2-positive breast cancer. $N$ Engl J Med. 2020;382:610-621. doi:10.1056/NEJMoa1914510

106. Modi S, Saura C, Yamashita T, et al. Updated results from DESTINY-Breast01, a phase 2 trial of trastuzumab deruxtecan (T-DXd) in HER2 positive metastatic breast cancer. San Antonio Breast Cancer Symp. 2020. PD3-PD06.

107. Jerusalem G, Park YH, Yamashita T, et al. CNS metastases in HER2-positive metastatic breast cancer treated with trastuzumab deruxtecan: DESTINY-Breast01 subgroup analyses. ESMO Breast Cancer Virtual Meeting. 2020;1380.

108. Tamura K, Tsurutani J, Takahashi S, et al. Trastuzumab deruxtecan (DS-8201a) in patients with advanced HER2-positive breast cancer previously treated with trastuzumab emtansine: a dose-expansion, phase 1 study. Lancet Oncol. 2019;20:816-826. doi:10.1016/S1470-2045(19)30097-X

\section{Publish your work in this journal}

Breast Cancer - Targets and Therapy is an international, peer-reviewed open access journal focusing on breast cancer research, identification of therapeutic targets and the optimal use of preventative and integrated treatment interventions to achieve improved outcomes, enhanced survival and quality of life for the cancer patient.
The manuscript management system is completely online and includes a very quick and fair peer-review system, which is all easy to use. Visit http://www.dovepress.com/testimonials.php to read real quotes from published authors. 